\title{
Apatite and Zircon Geochemistry in Yao'an Alkali-Rich Porphyry Gold Deposit, Southwest China: Implications for Petrogenesis and Mineralization
}

\author{
Yulin Zheng ${ }^{1,2}$, Changqing Zhang ${ }^{1, * \mathbb{C}}$, Fudong Jia ${ }^{1,3}$, Huan Liu ${ }^{1}$ and Qinggao Yan ${ }^{1,3}$ \\ 1 MLR Key Laboratory of Metallogeny and Mineral Assessment, Institute of Mineral Resources, \\ Chinese Academy of Geological Sciences, Beijing 100037, China; apostlelin@foxmail.com (Y.Z.); \\ jiafudong009@163.com (F.J.); xhhyliuhuan@163.com (H.L.); qinggaoy@126.com (Q.Y.) \\ 2 School of Resources and Environment Engineering, Hefei University of Technology, Hefei 230009, China \\ 3 School of Earth and Space Sciences, Peking University, Beijing 100871, China \\ * Correspondence: zcqchangqing@163.com
}

check for

updates

Citation: Zheng, Y.; Zhang, C.; Jia, F.; Liu, H.; Yan, Q. Apatite and Zircon Geochemistry in Yao'an Alkali-Rich Porphyry Gold Deposit, Southwest China: Implications for Petrogenesis and Mineralization. Minerals 2021, 11 1293. https://doi.org/min11111293

Academic Editor: Simon

Paul Johnson

Received: 19 October 2021

Accepted: 15 November 2021

Published: 20 November 2021

Publisher's Note: MDPI stays neutral with regard to jurisdictional claims in published maps and institutional affiliations.

Copyright: (C) 2021 by the authors Licensee MDPI, Basel, Switzerland. This article is an open access article distributed under the terms and conditions of the Creative Commons Attribution (CC BY) license (https:// creativecommons.org/licenses/by/ $4.0 /)$

\begin{abstract}
The Yao'an gold deposit is located in the middle of the Jinshajiang-Ailaoshan alkali-rich metallogenic belt, and this belt hosts many porphyry-type $\mathrm{Cu}-\mathrm{Au}-\mathrm{Mo}$ deposits formed at 46-33 Ma. Yao'an porphyry gold-mineralization is intimately associated with biotite syenite porphyry, whereas the contemporaneous quartz syenite porphyry is barren. In this study, we compared the major and trace elements of apatite and zircon and isotopic compositions of zircon from the biotite syenite porphyry and quartz syenite porphyry, to explore their geochemical differences that may affect their mineralization potential. The results show that both porphyries were derived from the partial melting of the thickened lower crust, which has been modified by slab-derived fluids, but has different mineral crystallization sequences, magma fluid activities, and magma oxidation states, respectively. REE contents in apatite and zircon can be used to reveal the crystallization sequence of minerals. A rapid decrease of $(\mathrm{La} / \mathrm{Yb})_{N}$ ratio in apatite from both porphyries may be caused by the crystallization of allanite. Large variation of $\mathrm{Cl}$ contents and negative correlation between $\mathrm{F} / \mathrm{Cl}$ and $(\mathrm{La} / \mathrm{Yb})_{\mathrm{N}}$ in apatite from fertile porphyry indicate that it has experienced the exsolution of $\mathrm{Cl}$-bearing hydrothermal fluid. Higher $\mathrm{Y} / \mathrm{Ho}$ and lower $\mathrm{Zr} / \mathrm{Hf}$ in zircon from fertile porphyry indicate a stronger fluid activity than barren porphyry. The high $\mathrm{S}, \mathrm{V}, \mathrm{As}$ contents, $\delta \mathrm{Eu}$, low $\delta \mathrm{Ce}$ in apatite, as well as high $\mathrm{Ce}^{4+} / \mathrm{Ce}^{3+}$ and $\log \left(\mathrm{fO}_{2}\right)$ estimated from zircon geochemistry from fertile porphyry, indicate high a oxidation state of fertile porphyry, similar to other fertile porphyries in this metallogenic belt. High fluid activity and fluid exsolution are conducive to the migration and enrichment of metal elements, which are very important for mineralization. High oxygen fugacity inhibits the precipitation of metal in the form of sulfide, thereby enhancing the mineralization potential of rock. Therefore, the exsolution of Cl-bearing hydrothermal fluid and high oxygen fugacity are the key factors promoting mineralization in Yao'an area.
\end{abstract}

Keywords: apatite; zircon; rare earth elements; fluid exsolution; oxygen fugacity; Yao'an

\section{Introduction}

Apatite and zircon are ubiquitous accessory minerals that can accommodate a variety of elements (REE, Sr, U, Th, Mn, S) in igneous rocks [1-4]. Therefore, such types of features make them powerful petrogenetic and ore-forming indicators in deciphering magma evolution history and genesis [5-11]. For example, apatite shows a strong preference in $\mathrm{Eu}^{3+}, \mathrm{Ce}^{3+}, \mathrm{S}^{6+}$ relative to $\mathrm{Eu}^{2+}, \mathrm{Ce}^{4+}, \mathrm{S}^{2-}$; therefore, their contents in apatite can be used to evaluate the oxidation state of magma $[12,13]$. The change of REE and halogen contents in apatite can be used to trace magma composition variation and the crystallization of other minerals [14-16]. Zircon geochemistry can be used to calculated zircon $\mathrm{Ce}^{4+} / \mathrm{Ce}^{3+}$ ratio and the $\log \left(f \mathrm{O}_{2}\right)$ of its host magma [17-19], thus providing robust parameters for magma redox conditions. In addition, apatite and zircon are widely used in U-Pb dating [20-23]. 
The Jinshajiang-Ailaoshan metallogenic belt, located in the eastern Indo-Asian collision zone, contains many alkali-rich porphyritic stocks and associated porphyry-type $\mathrm{Cu}-\mathrm{Au}-\mathrm{Mo}$ deposits (Figure 1), such as the Yulong porphyry Cu-Mo deposit [5,24-26], Beiya porphyry-skarn Au deposit [27-29], Machangqing Au-Cu-Mo deposit [29-33], Yao'an $\mathrm{Au}$ deposit [34-40], and Habo $\mathrm{Cu}-\mathrm{Mo}-\mathrm{Au}$ deposit [41-43]. Molybdenite Re-Os ages and zircon $\mathrm{U}-\mathrm{Pb}$ ages constrain the absolute timing of these porphyry-type deposits to $46-33 \mathrm{Ma}[5,22,29,38,42,44]$. In addition, coeval but barren porphyritic stocks, (e.g., Jianchuan quartz monzonitic granite porphyry and Liuhe syenite porphyry) are similarly widespread in the Jinshajiang-Ailaoshan magmatic belts. However, it remains obscure as to what control their contrasting ore-forming potential.

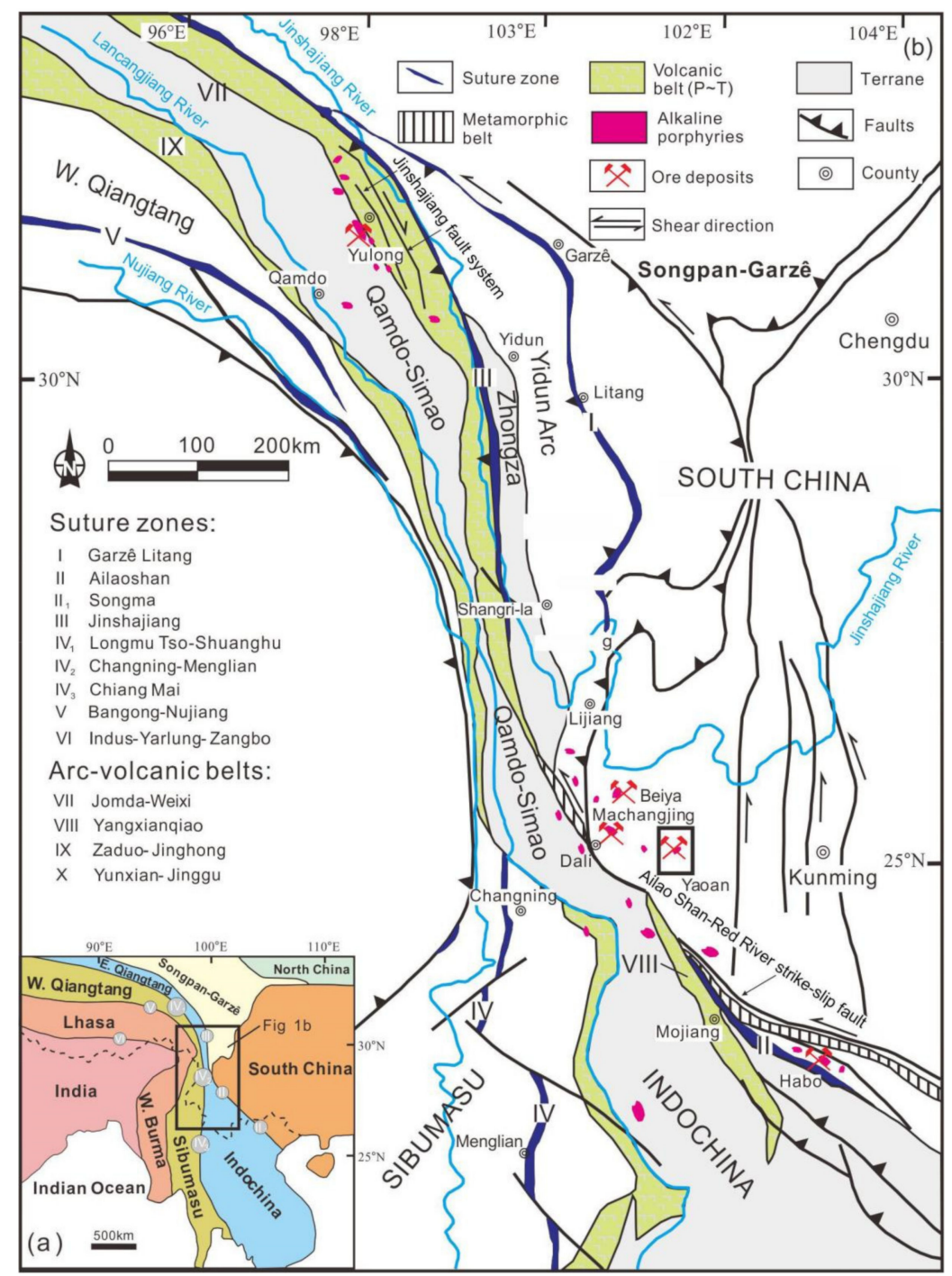

Figure 1. (a) Distribution of principal continental blocks and sutures of Southeast Asia [45]. (b) Tectonic framework of the Sanjiang domain in southwestern China, showing the major terranes, suture zones, arc volcanic belts, and location the Yao'an gold deposit and other primary intrusion-related $\mathrm{Cu}$-Au deposits [46,47].

In the Yao'an gold deposit, previous studies mainly focused on the geochronology and petrogenesis of syenite porphyry $[31,34,38,40]$. However, detailed studies on mineralogy are scarce in the Yao'an area, and it is especially unclear which factors control the difference in mineralization between fertile porphyry and barren porphyry. In this study, based on detailed mineralogical observations, the major and trace elements of apatite and zircon and Hf isotopes of zircon from the Yao'an syenite porphyry (including 'fertile' biotite 
syenite porphyry and 'barren' quartz syenite porphyry) were obtained. We also compared this data with those for other fertile and barren porphyries in this metallogenic belt. We discussed the magma evolution history, fluid activity, and oxygen fugacity of fertile and barren porphyry, for better understanding the differences in ore-forming potential.

\section{Regional Geology}

The Sanjiang polymetallic metallogenic belt is one of the most important parts of the Tethyan metallogenic belt. It is located in the southeast of the Tethyan tectonic domain and has experienced complex geological processes, particularly in the Cenozoic period. Since the Paleocene (65 Ma), a continental collision has occurred between the India and Asian plates. The orogenic process can be divided into three main stages: main collisional continental convergence (65-41 Ma), late collisional tectonic transformation (40-26 Ma), and post-collisional crustal extension (20-0 Ma) [24,48-54]. Several large-scale strike-slip fault and thrust systems were formed in Sanjiang area during the collision, such as the famous Jinshajiang-Ailaoshan strike-slip fault system. Many alkali-rich porphyry and porphyryrelated polymetallic deposits formed along the strick-slip faults [51,53,55-57], including the Yulong $\mathrm{Cu}-\mathrm{Mo}$ deposit, Beiya porphyry-skarn $\mathrm{Cu}-\mathrm{Au}$ deposit, Machangqing $\mathrm{Cu}-\mathrm{Mo}$ deposit, Yao' an gold deposit, and Habo Cu-Mo-Au deposit [5,22,30,31,34,35,38,41,42,46,58].

The Yao'an gold deposit is located in the Chuxiong basin within the Yangtze craton. In the deposit area, the main outcropped strata are mainly Lower Cretaceous (Gaofengshi Formation and Puchanghe Formation), Upper Cretaceous (Matoushan Formation and Jiangdihe Formation), and Quaternary. Many alkaline magmatic rocks are exposed in the area, including syenite porphyry (biotite syenite porphyry, quartz syenite porphyry), trachyte, pseudoleucite porphyry and lamprophyre $[37,38,59,60]$, and gold mineralization intimately associated with the syenite porphyry [34-36].

\section{Deposit Geology}

The Yao'an gold deposit was discovered in 1987 with approximately 10 tons gold resources [37]. The faults and folds in this area are well developed, including the mainly NW-plunging Laojiezi composite anticline. The NE-trending fault controls the emplacement of syenite porphyry and mineralization. The syenite porphyry can be divided into biotite syenite porphyry and quartz syenite porphyry, which are mainly distributed in Baimaju and Xiaocaiyuan, respectively. Gold is hosted in the Baimaju biotite syenite porphyry, whereas the Xiaocaiyuan quartz syenite porphyry is barren (Figure 2). Details of the petrographic characteristics are as follows.

The biotite syenite porphyry is grayish-white, and displays slight alteration with porphyritic textures (Figure 3c). Under the microscope, phenocrysts are dominated by orthoclase $(10 \mathrm{vol} \%)$, biotite $(5 \mathrm{vol} \%)$, and hornblende $(<5 \mathrm{vol} \%)$. The orthoclase phenocrysts are characterized by idiomorphic or hypidiomorphic textures with abundant fractures. Dark brown biotites and hornblendes are common mafic minerals, form euhedral to subhedral prisms of variable size, and contain apatite and zircon as mineral inclusions (Figure 3f,g). The composition of the matrix is similar to that of the phenocrysts. Apatite, magnetite, and zircon are found as accessory minerals (Figure $3 \mathrm{e}-\mathrm{g}$ ). 


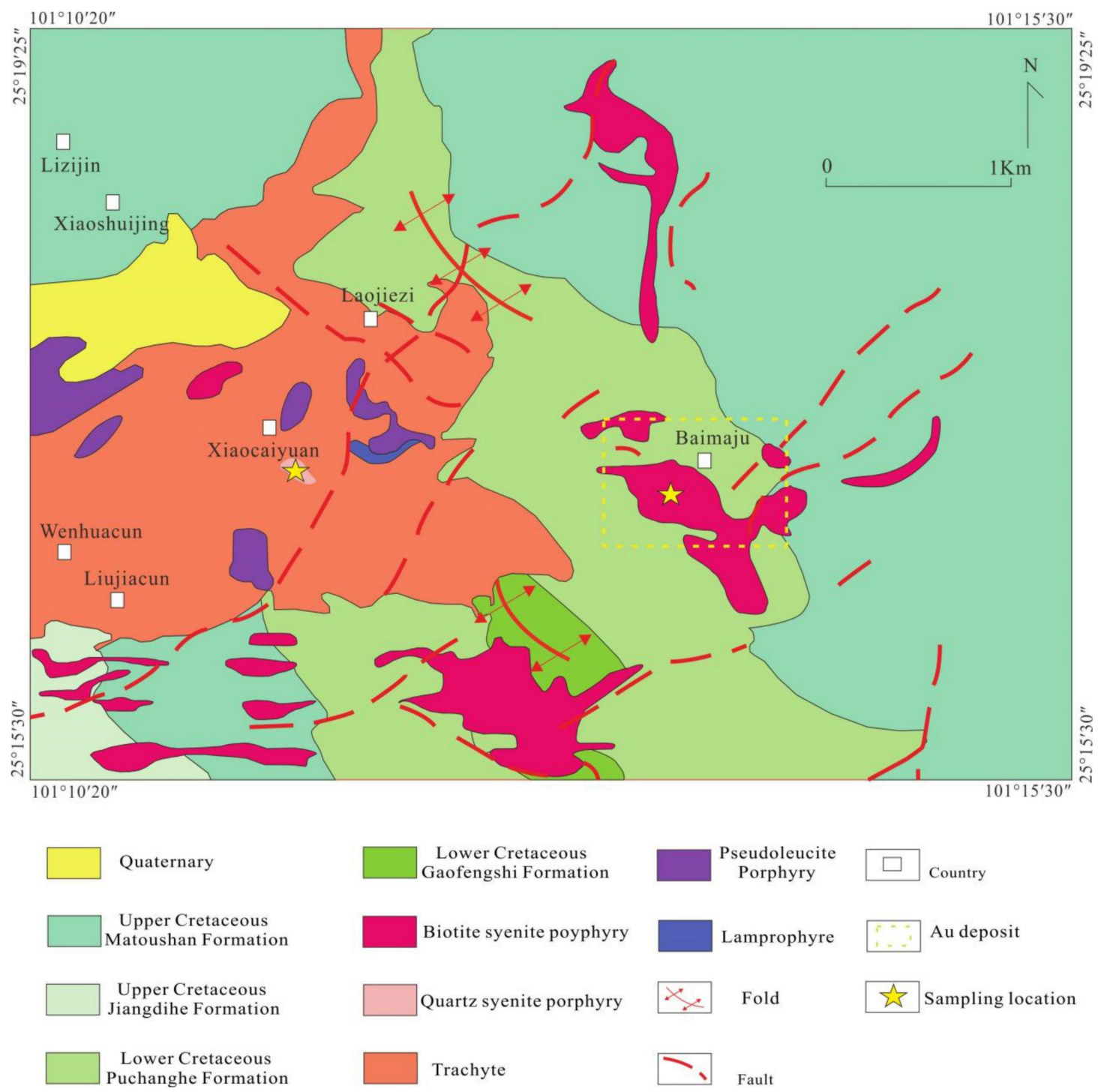

Figure 2. Simplified geological map of the Yao'an gold deposit, showing the distribution of the Yao'an alkaline volcanicmagmatic complex [35].

The quartz syenite porphyry is light gray, displays slight alteration, porphyritic textures, and block structures (Figure 3d). Under the microscope, phenocrysts are mainly orthoclase $(10 \mathrm{vol} \%)$, quartz ( $5 \mathrm{vol} \%)$, with traces of biotite $(<5 \mathrm{vol} \%)$, without hornblende. The orthoclase phenocrysts are typically subhedral to euhedral, have undergone clay alteration, and contain apatite and zircon as a mineral inclusion (Figure 3j,k). The quartz phenocrysts show harbor-like shapes or are finely granular. The groundmass composition is similar to that of the phenocrysts. The accessory minerals are mainly apatite, magnetite, zircon, and titanite. The content of hydrous minerals is lower than that in the biotite syenite porphyry (Figure $3 \mathrm{i}-\mathrm{k}$ ). 


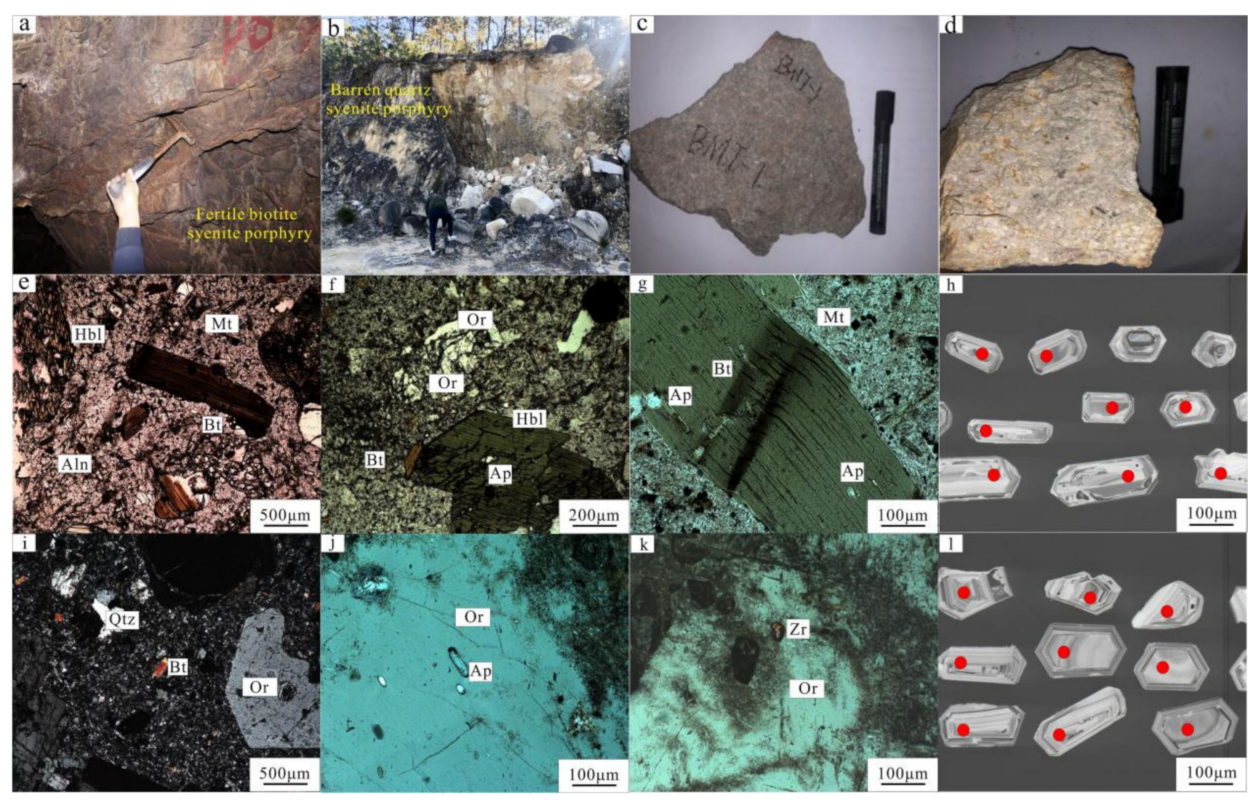

Figure 3. Field photographs, micrographs and CL images illustrating the petrographic, characteristics of rock samples, and the occurrence features of apatite grans. $(\mathbf{a}, \mathbf{b})$ Field photographs of fertile biotite syenite porphyry and barren quartz syenite poyphyry; (c,d) Hand specimen of biotite syenite porphyry and quartz syenite porphyry; (e-g) Microscopic characteristic of biotite syenite porphyry, show apatite grains are enclosed in hornblende and biotite; cross-polarized light; (h,l) CL images of apatites from biotite syenite porphyry and quartz syenite porphyry, show clearly oscillatory zone; (i-k) Microscopic characteristic of quartz syenite porphyry, show apatite and zircon grains are enclosed inorthoclase; cross-polarized light; $(\mathbf{k}, \mathbf{l})$ CL image of zircon and apatite from quartz syenite porphyry, show clearly oscillatory zone. Red circle are analysis points of EMPA and LA-ICP-MS respectively. Abbreviations: $\mathrm{Or}=$ orthoclase, $\mathrm{Bt}=$ biotite, $\mathrm{Hbl}=$ hornblende, Ap $=$ apatite, $\mathrm{Qtz}=$ quartz, $\mathrm{Mt}=$ magnetite, Aln = allanite.

\section{Sampling and Analytical Methods 4.1. Sampling}

The biotite syenite porphyry (fertile porphyry) sample was collected from the Baimaju outcrop (Figure 3a); the quartz syenite porphyry (barren porphyry) was collected from the Xiaocaiyuan outcrop (Figure 3b). Zircon and apatite were separated by traditional density and magnetic methods and were then picked manually under a microscope. In order to investigate the internal characteristics of the zircon and apatite, polished sections of zircon and apatite were carbon coated for cathodoluminescence (CL) imaging. These work were completed at the Langfang Sincerity Geological Service Co., Ltd., Hebei, China.

\subsection{EMPA and LA-ICP-MS of Apatite and Zircon}

Major elements of the apatite were analyzed using a JEOL-JXA8230 electron microprobe analyzer (EMPA) in wavelength-dispersive spectrometry (WDS) mode in the MLR Key Laboratory of Metallogeny and Mineral Assessment, Institute of Mineral Resources, Chinese Academy of Geological Sciences, Beijing, China. The operating conditions include a $15 \mathrm{kV}$ accelerating voltage, a $10 \mathrm{nA}$ beam current, and a $5 \mu \mathrm{m}$ beam diameter. To detect the characteristic X-ray patterns, twenty seconds (s) of counting time was chosen for most elements, whereas $20 \mathrm{~s}$ was chosen for $\mathrm{F}$ and $10 \mathrm{~s}$ was chosen for $\mathrm{P}$ and $\mathrm{Ca}$. Natural minerals and synthetic materials were used as standards, and all of the standards were tested for homogeneity before their utilization for quantitative analyses. Matrix corrections were carried out using the ZAF correction program supplied by the instrument manufacturer.

Laser-ablation inductively coupled plasma mass spectrometer (LA-ICP-MS) trace element analyses of apatite and zircon were performed at the National Research Center for Geoanalysis, Chinese Academy of Geological Sciences, Beijing, China, using a Finnigan MAT ELEMENT II high-solution inductively coupled plasma spectrometer (HR-ICP-MS) 
with a high-performance interface coupled with a New-Wave UP-193 nm Nd: YAG UV laser. Ablation was carried out by a He-Ar gas mixture (flow rate of $0.73 \mathrm{~L} \mathrm{He} / \mathrm{min}$ and $0.85 \mathrm{~L} \mathrm{Ar} / \mathrm{min}$ ) and the resulting vapor was combined with argon before delivery into the ICP-MS. The analyses were conducted using a $35-\mu \mathrm{m}$ spot diameter, a $10-\mathrm{Hz}$ frequency, a $0.25-\mathrm{mJ} /$ pulse power, during a 70-s analysis including $20 \mathrm{~s}$ measurement of gas blank, followed by ablation of the sample for approximately $40 \mathrm{~s}$ by raster. Each group of ten apatite analyses was bracketed by analysis of standard glass NIST612, NIST 610, and K12 to correct for mass bias drift during analytical session. The calibration were completed using internal standards and matrix normalization. The Ca content determined by EPMA was used as the internal standard for trace-element determinations by LA-ICP-MS.

\subsection{Zircon Hafnium Isotopes}

Hf isotope analyses were conducted using a LA-MC-ICP-MS. The detailed analytical procedures were described by [61]. A beam diameter of 40-60 $\mu \mathrm{m}$ was used, and helium carrier gas transported the ablated aerosol from the laser-ablation cell via a mixing chamber to the ICP-MS torch. The zircon standard GJ1 was analyzed to evaluate the accuracy of the laser-ablation results. Throughout the session, GJ1 yielded a mean value of ${ }^{176} \mathrm{Hf} /{ }^{177} \mathrm{Hf}=0.282015 \pm 0.000008(2 \sigma, \mathrm{n}=10)$, which was consistent with error with the published standard value [62]. To calculate the $\varepsilon \mathrm{Hf}$ values, we adopted the chondritic values of [63], that is $\left({ }^{176} \mathrm{Hf} /{ }^{177} \mathrm{Hf}\right)_{\mathrm{CHUR}}=0.032$ and $\left({ }^{176} \mathrm{Hf} /{ }^{177} \mathrm{Hf}\right)_{\mathrm{CHUR}}=0.282772$. We also used the decay constant $\lambda=1.865 \times 10$ year in the $\varepsilon H f$ calculations. To calculate depleted-mantle model ages $\left(\mathrm{T}_{\mathrm{DM} 1}\right)$, we adopted the values of $\left({ }^{176} \mathrm{Lu} /{ }^{177} \mathrm{Hf}\right)_{\mathrm{DM}}=0.0384$ and $\left({ }^{176} \mathrm{Hf} /{ }^{177} \mathrm{Hf}\right)_{\mathrm{DM}}=0.28325$ [64]. Here, we calculated two-stage model ages $\left(T_{\mathrm{DM} 2}\right)$, which assumed that the parental magma was produced from average continental crust (i.e., $\left.{ }^{176} \mathrm{Lu} /{ }^{177} \mathrm{Hf}=0.015\right)$ that was derived from depleted mantle [65].

\section{Results}

In this article, we have obtained a total of 40 major elements and 40 trace elements in apatites. 50 trace elements and $28 \mathrm{Hf}$ isotope were analyses for zircon. Apatite major and trace elements are listed in Table S1, and zircon trace elements and Hf isotopes are listed in Table S2.

\subsection{Apatite Halogens and Major Elements}

Apatites from fertile and barren porphyry have similar $\mathrm{CaO}$ (54.28 to $55.28 \mathrm{wt} . \%)$, $\mathrm{P}_{2} \mathrm{O}_{5}$ (39.48 to 41.27 wt.\%) and $\mathrm{F}$ (2.73 to 3.43 wt. \%) contents, but are different in $\mathrm{Cl}$ and $\mathrm{SO}_{3}$ contents. The results show that all of the apatite grains are enriched in $\mathrm{F}$ relative to $\mathrm{Cl}$, which we classified them as fluorapatite and have magmatic feature (Figure 4a). Apatite from barren porphyry shows slight $\mathrm{Cl}$ variation and low $\mathrm{Cl}$ contents $(0.03$ to $0.11 \mathrm{wt} . \%$, average $0.07 \mathrm{wt} . \%$ ), high $\mathrm{F} / \mathrm{Cl}$ ratios (31.15 to 105.61 , average 50.55 ). In contrast, apatite from fertile porphyry shows a large $\mathrm{Cl}$ variation, high $\mathrm{Cl}$ contents $(0.13$ to $0.71 \mathrm{wt} . \%$, average $0.50 \mathrm{wt} . \%)$, and low $\mathrm{F} / \mathrm{Cl}$ ratio (4.31 to 27.20 average 9.14$)$. In addition, apatite from fertile porphyry has higher $\mathrm{SO}_{3}$ contents $(0.17$ to $0.71 \mathrm{wt} . \%$, average $0.42 \mathrm{wt} . \%)$ than apatite from barren porphyry (0.01 to $0.47 \mathrm{wt} . \%$, average $0.15 \mathrm{wt} . \%$ )

\subsection{Apatite Trace Elements}

Apatite grains from fertile porphyry have higher Sr (1308 to $4856 \mathrm{ppm}, 2631 \mathrm{ppm}$ on average), As ( 38 to $127 \mathrm{ppm}$, average $75 \mathrm{ppm}$ ), and V ( 3 to $30 \mathrm{ppm}$, average $14 \mathrm{ppm}$ ) contents than apatite from barren porphyry Sr (1298 to $3675 \mathrm{ppm}$, average $2049 \mathrm{ppm}$ ), As (39 to $101 \mathrm{ppm}$, average $64 \mathrm{ppm}$ ), and V (2 to $19 \mathrm{ppm}$, average $10 \mathrm{ppm}$ ). 

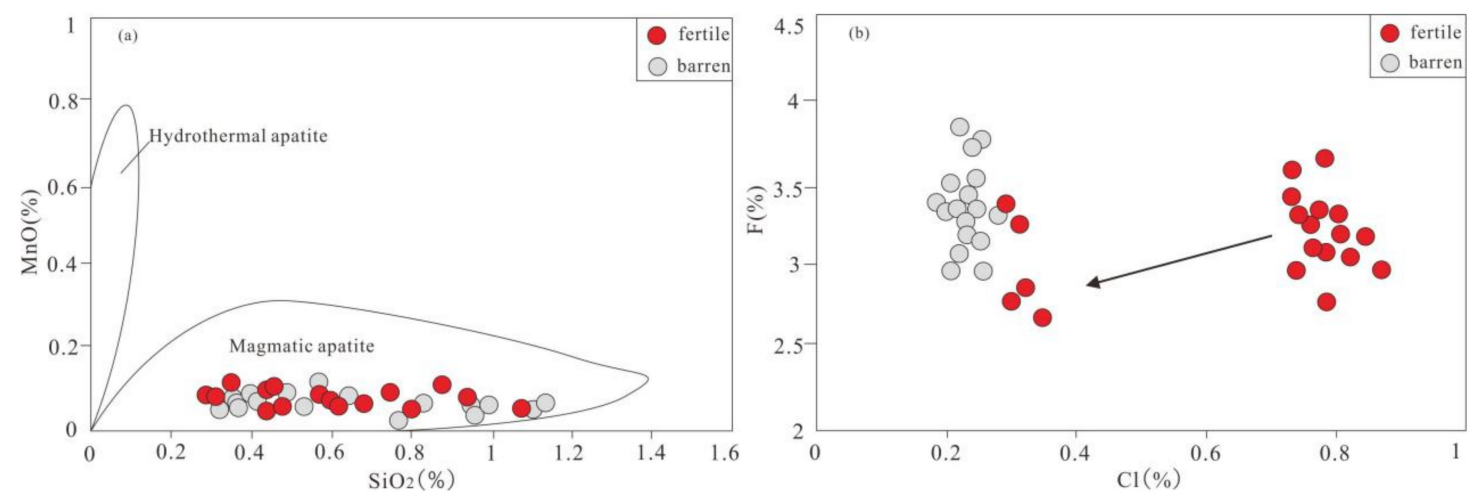

Figure 4. (a) Apatite genesis diagram, plots of $\mathrm{SiO}_{2}$ versus $\mathrm{MnO}$ [66]; (b) $\mathrm{Cl}$ versus $\mathrm{F}$ in apatite, high $\mathrm{Cl}$ content and large $\mathrm{Cl}$ variation in apatite from fertile porphyry.

The Chondrite-normalized REE patterns of apatites are all enriched in LREE and depleted in HREE (Figure 5). Apatites from barren porphyry have similar $\sum$ REE contents and $(\mathrm{La} / \mathrm{Yb})_{\mathrm{N}}$ ratio (9969 to 35,869 ppm, average 19,454 ppm; 56 to 210, average 125) with apatite from fertile porphyry $\sum \mathrm{REE}$ and $(\mathrm{La} / \mathrm{Yb})_{\mathrm{N}}(5448$ to 37024 , average $18,659 \mathrm{ppm}$; 27 to 245 , average 126), higher $\delta \mathrm{Ce}$ (1.63 to 1.91 , average 1.73 ), and lower $\delta \mathrm{Eu}$ (0.59 to 0.72 , average 0.67 ) values in apatite from barren porphyry relative to apatite from fertile porphyry $\delta \mathrm{Ce}(1.34$ to 1.68 , average 1.55$), \delta \mathrm{Eu}(0.66$ to 0.86 , average 0.75$)$.

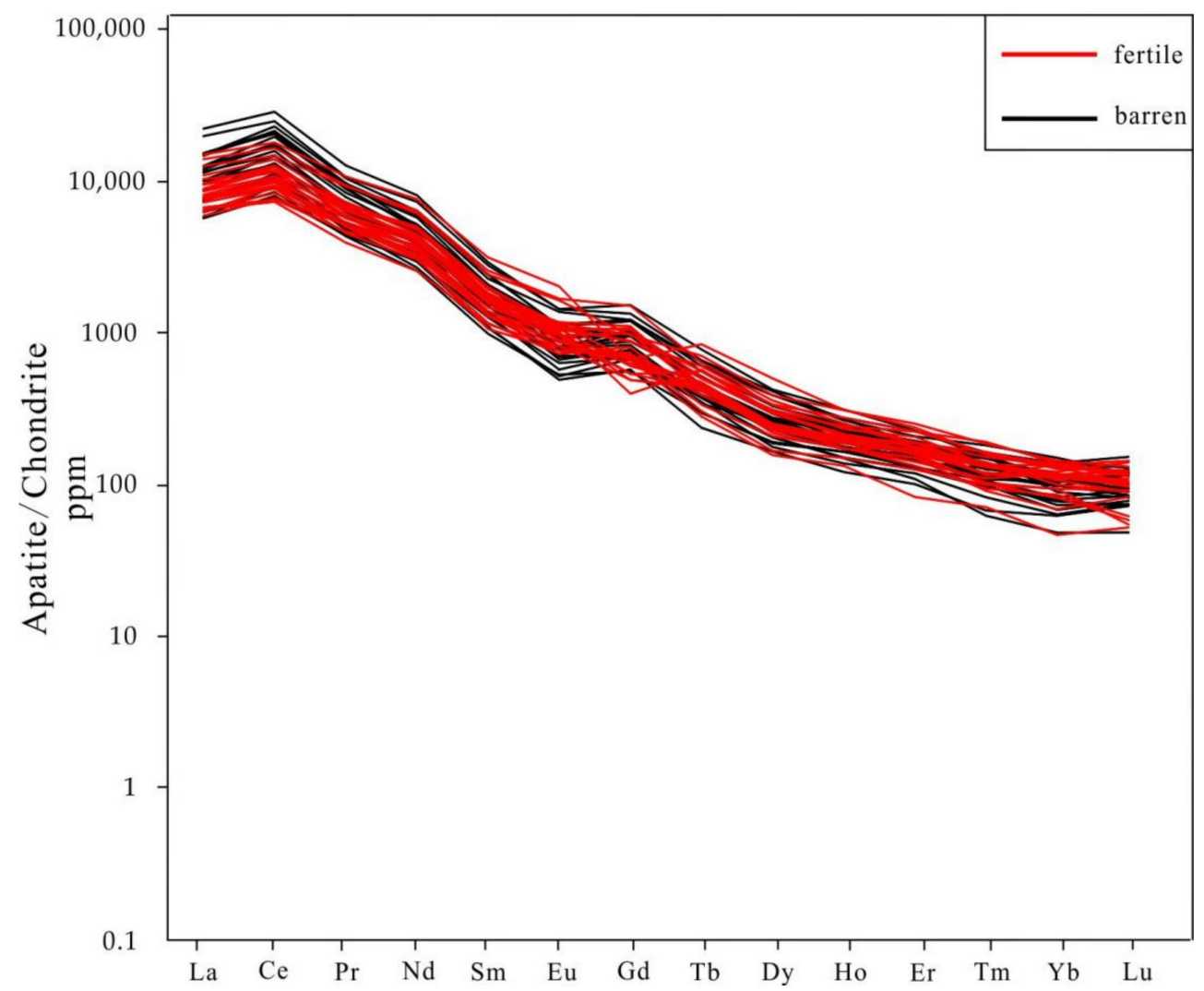

Figure 5. Apatite REE patterns of samples from the Yao'an gold deposit [67]. The chondrite-normalized patterns are depleted in HREE and enriched in LREE and are characterized by positive Ce anomalies with negative $\mathrm{Eu}$ anomalies.

\subsection{Zircon Trace Elements}

Chondrite-normalized patterns show that all the zircons are enriched in HREE and depleted in LREE, with positive Ce anomalies and variable negative Eu anomalies (Figure 6). 
Zircon from fertile porphyry has lower $\sum$ MREE contents (47 to $195 \mathrm{ppm}$, average $112 \mathrm{ppm}$ ), $\mathrm{Zr} / \mathrm{Hf}$ ratio (58 to 75, average 64) than it from barren porphyry $\sum$ MREE contents (153 ppm to $578 \mathrm{ppm}$, average $252 \mathrm{ppm}$ ), $\mathrm{Zr} / \mathrm{Hf}$ ratio (64 to 91 , average 80 ). However, $\Sigma$ LREE/ $\Sigma \mathrm{MREE}$ ratio ( 0.36 to 0.72 , average 0.52$), \mathrm{U} / \mathrm{Th}$ ratio ( 0.76 to 1.93 , average 1.19$), \mathrm{Yb} / \mathrm{Dy}$ ratio (10.33 to 13.29 , average 11.79 ), $\delta$ Ce value (4 to 275 , average 82 ) and $Y /$ Ho ratio (29 to 37 , average 33 ) in zircon from fertile porphyry are higher than it from barren porphyry $(0.23$ to 0.57 , average $0.37 ; 0.26$ to 0.87 , average $0.55 ; 7$ to 11 , average $9 ; 4$ to 106 , average $37 ; 26$ to 33 , average 29). Ti contents in zircon from both porphyries are similar (fertile: $\mathrm{Ti}=18 \mathrm{ppm}$ to $24 \mathrm{ppm}$, average $21 \mathrm{ppm}$; barren: $17 \mathrm{ppm}$ to $23 \mathrm{ppm}$, average $20 \mathrm{ppm}$ ).

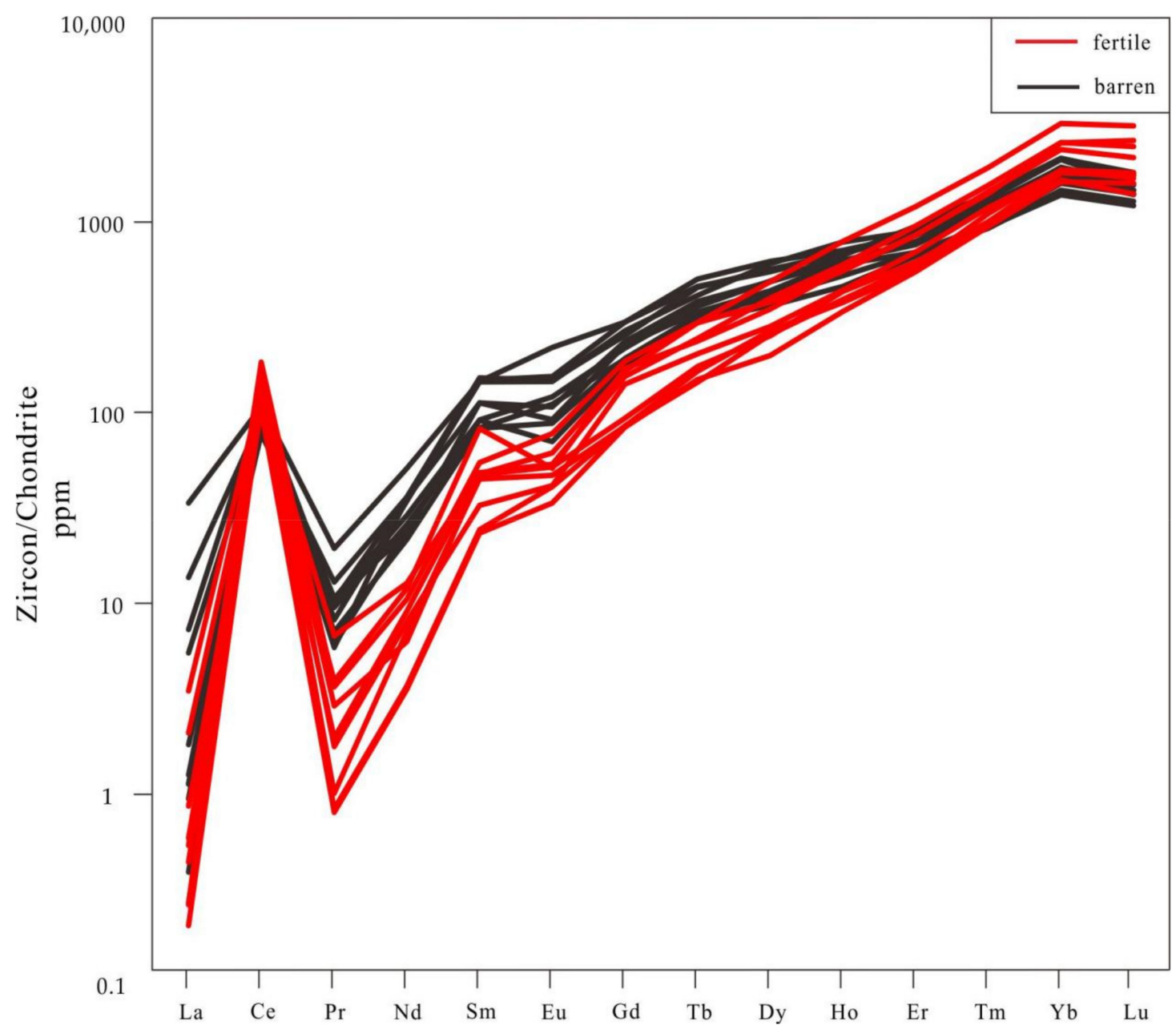

Figure 6. Zircon REE patterns of samples from the Yao'an gold deposit [67]. The chondrite-normalized patterns are depleted in LREE and enriched in HREE and are characterized by positive Ce anomalies with variable negative Eu anomalies.

\subsection{Zircon Hf Isotopes}

Zircon Hf analysis and calculated $\varepsilon \mathrm{Hf}$ and $\mathrm{T}_{\mathrm{DM} 2}$ from all samples are listed in Table S2. Fourteen spots analyzed on zircon from fertile porphyry show ${ }^{176} \mathrm{Hf} /{ }^{177} \mathrm{Hf}$ ratios ranging from 0.282545 to 0.282442 ; $\varepsilon$ Hf values varying from -11.38 to -7.75 ( -10.17 on average). The two-stage Hf depleted mantle-model ages $\left(\mathrm{T}_{\mathrm{DM} 2}\right)$ range from 1.80 to $1.57 \mathrm{Ga}$ (average $1.72 \mathrm{Ga}$ ). Fourteen spots analyzed on zircon from barren porphyry showed ${ }^{176} \mathrm{Hf} /{ }^{177} \mathrm{Hf}$ ratios ranging from 0.282464 to 0.282333 ; $\varepsilon \mathrm{Hf}$ values varied from -15.24 to -10.61 (average -12.36 ); the two-stage Hf depleted mantle-model ages $\left(\mathrm{T}_{\mathrm{DM} 2}\right)$ ranged from 2.04 to $1.75 \mathrm{Ga}$ (average $1.86 \mathrm{Ga}$ ). Zircon from fertile and barren porphyry showed similar ${ }^{176} \mathrm{Hf} /{ }^{177} \mathrm{Hf}$ ratios and $\mathrm{Hf}$ depleted mantle-model ages $\left(\mathrm{T}_{\mathrm{DM} 2}\right)$, and strongly negative $\varepsilon$ Hf values. 


\section{Discussion}

\subsection{Apatite and Zircon Geochemistry as Indicators of Magma Crystallization Sequence}

Apatite and zircon trace element compositions are mainly controlled by magma composition, partition coefficient between apatite/zircon and melt, and crystallization of other minerals. As such, they can be used as good indicators to trace magma fractional crystallization [8,68-73].

$\mathrm{Th} / \mathrm{U}$ ratios of zircon from fertile and barren porphyry are negatively correlated with $\mathrm{Yb} / \mathrm{Gd}$ ratios (Figure 7a), indicating that they have experienced the effects of fractional crystallization [72]. Ce/Sm and $\mathrm{Yb} / \mathrm{Gd}$ ratios in zircon can be used to reveal the growth sequence of minerals [72], In Ce/Sm versus $\mathrm{Yb} / \mathrm{Gd}$ diagram (Figure $7 \mathrm{~b}$ ), zircon from fertile and barren porphyry plots in similar field, reflect that their compositions were effected by crystallization of titanite or hornblende. Zircon from fertile porphyry has lower $\sum$ MREE/ $\sum$ HREE than those from barren porphyry, which indicates that zircon from fertile porphyry was mainly affected by hornblende, while zircon from barren porphyry mainly was affected by titanite, as hornblende is known to concentrate the MREE but titanite concentrated the HREE $[74,75]$. In addition, titanite is enriched in $\mathrm{U}$ and less in Th, and $\mathrm{Yb}$ has lower partition coefficient than Dy in hornblende [76], therefore zircon crystallizing late will have lower $\mathrm{U} / \mathrm{Th}$ and higher $(\mathrm{Yb} / \mathrm{Dy})_{\mathrm{N}}$ ratio than crystallizing earlier. Lower $\mathrm{U} / \mathrm{Th}$ and $(\mathrm{Yb} / \mathrm{Dy})_{\mathrm{N}}$ ratio in zircon from barren porphyry than those from fertile porphyry (Figure 8a), further indicating that zircon from barren porphyry was mainly affected by titanite, and zircon from fertile porphyry was mainly affected by hornblende. Moreover, most of the zircon grains were wrapped in feldspar, which indicates that zircon crystallizes earlier than feldspar.
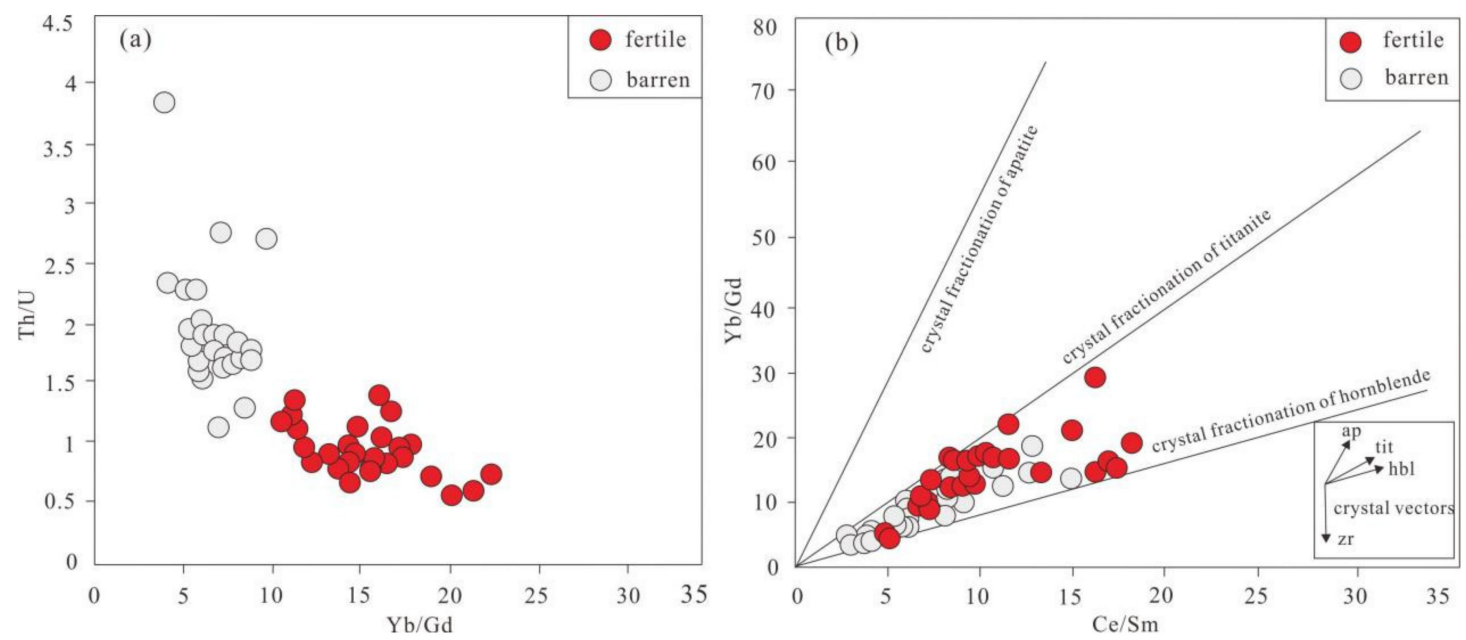

Figure 7. (a) Plots of zircon $\mathrm{Yb} / \mathrm{Gd}$ vs. Th/U diagram, show negative correlation [72]; (b) Ce/Sm ratio versus $\mathrm{Yb} / \mathrm{Gd}$ ratios in zircon [73]. The crystal vector in (b) showed the crystal fractionation of apatite (ap), titanite (tit), hornblendes (hbl), and zircon (zr).

We used the apatite-saturation temperature calculation formula and Ti in zircon to estimate the crystallization temperature of apatite and zircon [77]. In this study, apatites having a higher crystallization temperature $\left(876\right.$ to $\left.987^{\circ} \mathrm{C}\right)$ than zircons $\left(792\right.$ to $\left.825^{\circ} \mathrm{C}\right)$, indicating that apatite crystallized earlier than zircon. In addition, the rapid decrease of $(\mathrm{La} / \mathrm{Yb})_{\mathrm{N}}$ value in apatite (Figure $8 \mathrm{~b}$ ) indicates the crystallization of allanite [74,75]. Therefore, the crystallization sequence of minerals in this article is as follows: allaniteapatite-hornblende-zircon-feldspar in fertile porphyry, and allanite-apatite- titanite-zirconfeldspar in barren porphyry. Furthermore, [7] we proposed that $\mathrm{Sr} / \mathrm{Y}$ and $\delta \mathrm{Eu}$ in apatite are good indicators for adakitic-like rocks, especially in altered or weathered rocks. As shown in Figure 9a, all apatites fall into the adakitic rock area. 

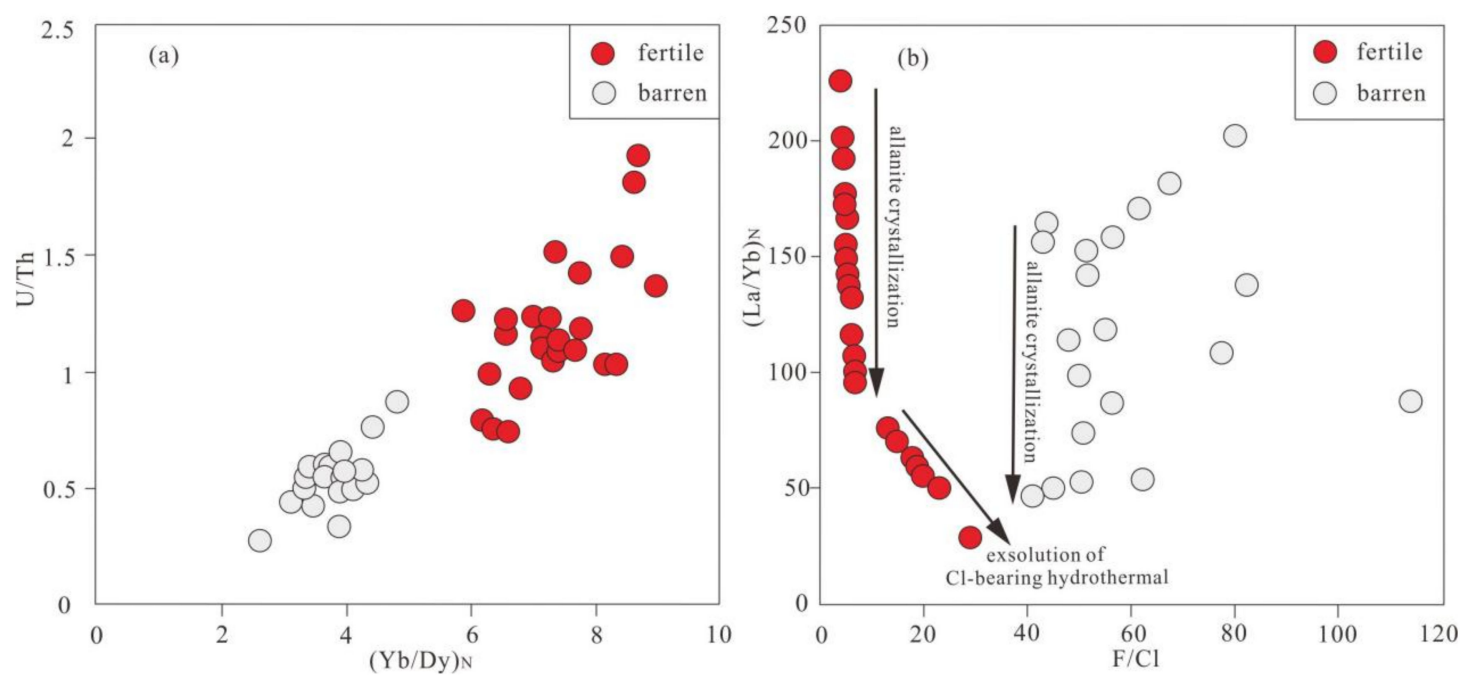

Figure 8. (a) Plots of U/Th vs. $(\mathrm{Yb} / \mathrm{Dy})_{\mathrm{N}}$ in zircon [76]; (b) Plot of $(\mathrm{La} / \mathrm{Yb})_{\mathrm{N}}$ vs. F/Cl in apatite [7].
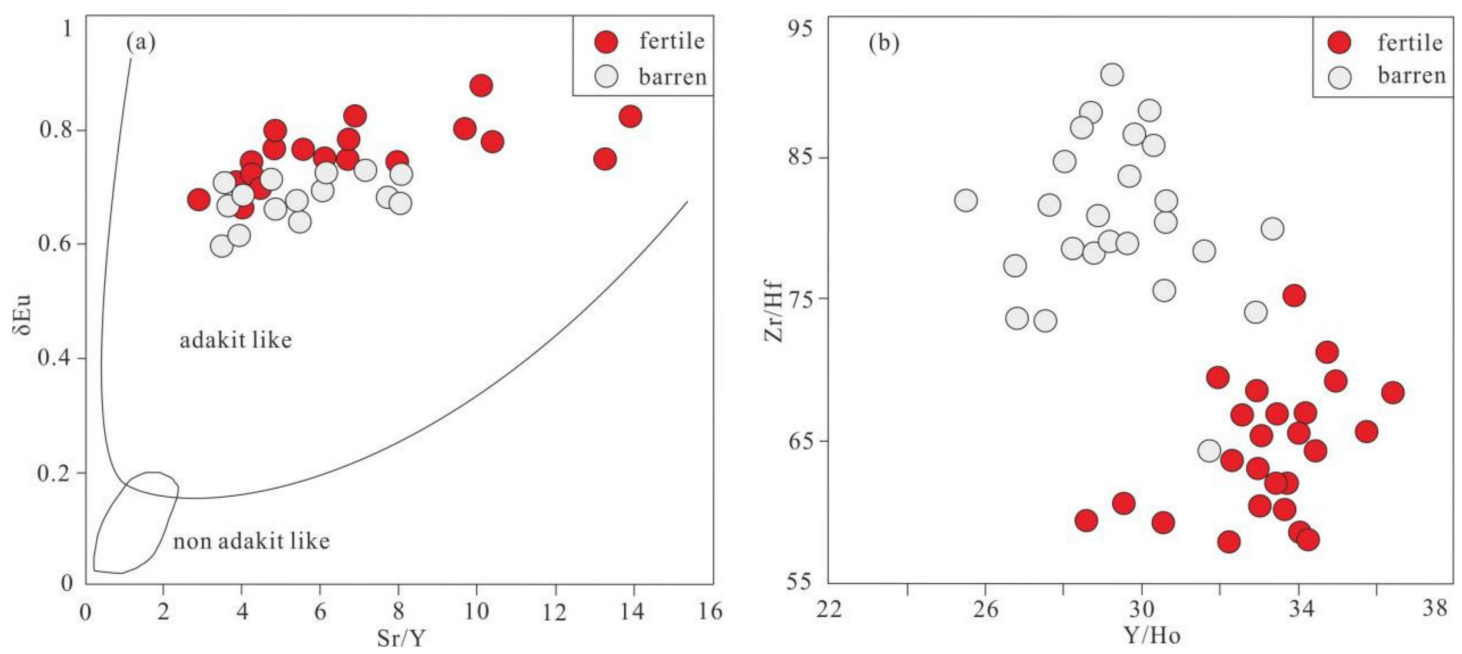

Figure 9. (a) Plot of $\delta$ Eu vs. Sr/Y in apatite [7]; (b) Plots of $\mathrm{Y} / \mathrm{Ho}$ vs. Zr/Hf in zircon [11,78].

\subsection{Fluid Activity and Exsolution Is Favorable to Mineralization}

$\mathrm{Y} / \mathrm{Ho}$ and $\mathrm{Zr} / \mathrm{Hf}$ ratios in zircon and $\mathrm{Cl}$ contents in apatite are important parameters to indicate magma fluid activity [11,78]. The $\mathrm{Y} / \mathrm{Ho}$ ratio of chondrites is 27.7 , and usually in the absence of fluid interaction, $\mathrm{Y} / \mathrm{Ho}$ ratio in zircon maintained from 24-34. Strong magmatic fluid activity can promote the differentiation of $\mathrm{Y}$ and Ho; therefore, zircon crystallized from magma with strong fluid activity has a high $\mathrm{Y} / \mathrm{Ho}$ ratio [78]. Zr and Hf has the same ionic radius and valence, strong fluid activity, and can promote more Hf to substitute $\mathrm{Zr}$ in zircon [78]. $\mathrm{Cl}$, as an incompatible element, more readily enters the fluid phase than $\mathrm{F}$ during magma evolution [79-86]; therefore, high $\mathrm{Cl}$ contents and $\mathrm{Cl} / \mathrm{F}$ ratios in apatite may be related to the high water content of magma.

Compared with zircon in the barren porphyry, zircon from fertile porphyry has higher $\mathrm{Y} / \mathrm{Ho}$ and lower $\mathrm{Zr} / \mathrm{Hf}$ ratios (Figure $9 \mathrm{~b}$ ), which indicates that the fluid activity in fertile porphyry is stronger. Apatite from fertile porphyry displays a higher $\mathrm{Cl}$ content relative to apatite in the barren porphyry, which indicates a higher water content of fertile porphyry. High fluid activity and water contents can cause the magma to readily reach water saturation and fluid exsolution during its evolution. As shown in Figure $4 \mathrm{~b}, \mathrm{Cl}$ contents in apatite from fertile porphyry decreased rapidly, $\mathrm{F} / \mathrm{Cl}$ ratio in apatite from fertile porphyry show negative correlation with $(\mathrm{La} / \mathrm{Yb})_{\mathrm{N}}$ ratio (Figure $8 \mathrm{~b}$ ), indicating that fertile porphyry 
experienced exsolution of $\mathrm{Cl}$-bearing hydrothermal, because $\mathrm{Cl}$-bearing hydrothermal can carry more LREE relative to HREE and MREE. In addition, the crystallization of allanite can also lead to the decrease of $(\mathrm{La} / \mathrm{Yb})_{\mathrm{N}}$ value; as shown in Figure 8b, rapid decrease of $(\mathrm{La} / \mathrm{Yb})_{\mathrm{N}}$ value but constant $\mathrm{F} / \mathrm{Cl}$ ratio indicates the crystallization of allanite, consistent with the observation of allanite under the microscope (Figure 3e). Furthermore, high $\mathrm{Cl}$ contents in apatite from fertile porphyry indicates that $\mathrm{Cl}$ is rich in magmatic fluid and since metal elements easily combine with $\mathrm{Cl}$ to form soluble complexes, this is conducive to the migration and enrichment of metal elements [87-89].

\subsection{Magma Oxidation State}

The contents of redox-sensitive elements such as $\mathrm{Eu}, \mathrm{Ce}, \mathrm{S}, \mathrm{V}$ and $\mathrm{As}$ in apatite and $\mathrm{Ce}^{4+} / \mathrm{Ce}^{3+}$ ratio in zircon can be used to evaluate the oxidation state of magma [12-14,90-100].

Both $\mathrm{Eu}$ and Ce have two valence states $\left(\mathrm{Eu}^{2+}, \mathrm{Eu}^{3+} ; \mathrm{Ce}^{3+}, \mathrm{Ce}^{4+}\right)$. Eu enters apatite in high valence, while Ce in low valence [12,91]. As shown in Figure 10a, $\delta \mathrm{Eu}$ and $\delta \mathrm{Ce}$ appear in an obvious negative correlation, indicate their contents in apatite are mainly controlled by oxygen state of magma. High $\delta \mathrm{Eu}$ and low $\delta \mathrm{Ce}$ in fertile porphyry indicate high oxidation state of the magma.
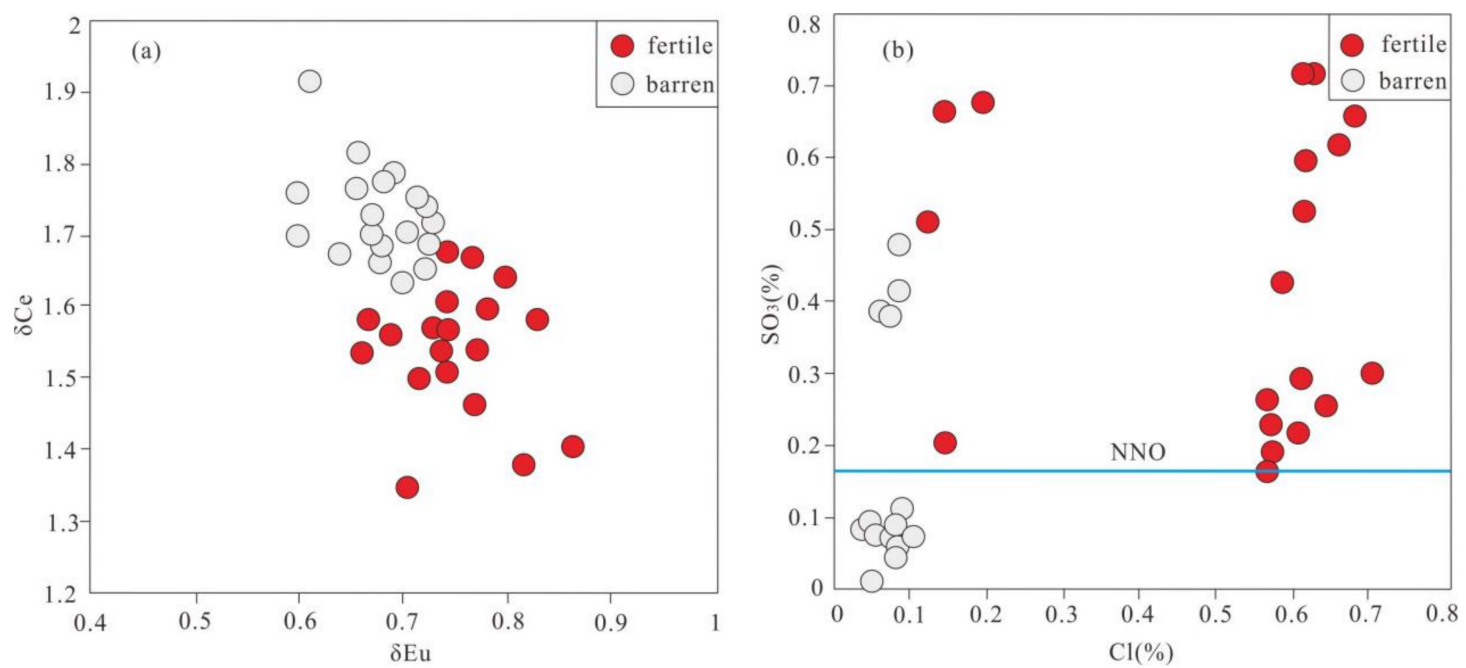

Figure 10. (a) Plots of $\delta \mathrm{Eu}$ vs. $\delta \mathrm{Ce}$ in apatite; (b) Plots of $\mathrm{SO}_{3}$ vs. $\mathrm{Cl}$ contents (\%) in apatite. The nickle-nickle oxide buffer (NNO) line is from [94].

$\mathrm{S}, \mathrm{V}$ and $\mathrm{As}$ has variable valence states $(-2,+4,+6)$, and $\mathrm{S}^{6+} ; \mathrm{As}^{6+} ; \mathrm{V}^{6+}$ are favored by apatite. High S, V and As in apatite from fertile porphyry, indicate high oxidation state of fertile porphyry. In addition, all apatite from fertile porphyry and only four apatites from barren porphyry lie above the NNO buffer line (Figure 10b), which indicate higher oxidation state of fertile porphyry than those of the barren porphyry.

Ce has two valence states $(+3$ and +4$)$, and $\mathrm{Ce}^{4+}$ is favored by zircon because it can substitute $\mathrm{Zr}^{4+}$, which makes the zircon show positive Ce anomaly. In addition, Zircon can also be used to calculate $f \mathrm{O}_{2}$ of its host magma [17-19,101]. The calculated $\mathrm{Ce}^{4+} / \mathrm{Ce}^{3+}$ and $\log \left(f \mathrm{O}_{2}\right)$ in zircon from fertile porphyry (54 to 429 , average $134 ;-16$ to -3 , average -8 ) are higher than it from barren porphyry ( 6 to 25 average $156 ;-18$ to -8 , average -12), indicate that fertile porphyry has higher oxygen fugacity than barren porphyry (Figure 11a; Figure 12a,b). Previous studies have shown that the Ce/Nd and Ce/Sm ratio from zircon are positively correlated with oxygen fugacity [9]. Here, the higher $\mathrm{Ce} / \mathrm{Nd}$ and $\mathrm{Ce} / \mathrm{Sm}$ ratios in zircon from fertile porphyry are consistent with previous studies (Figure 11b). Compared with other fertile porphyry in the metallogenic belt, we can see that fertile porphyry in Beiya and Machangqing is characterized by high oxygen fugacity, whereas the Liuhe barren porphyry shows low oxygen fugacity (Figure 12a,b). 

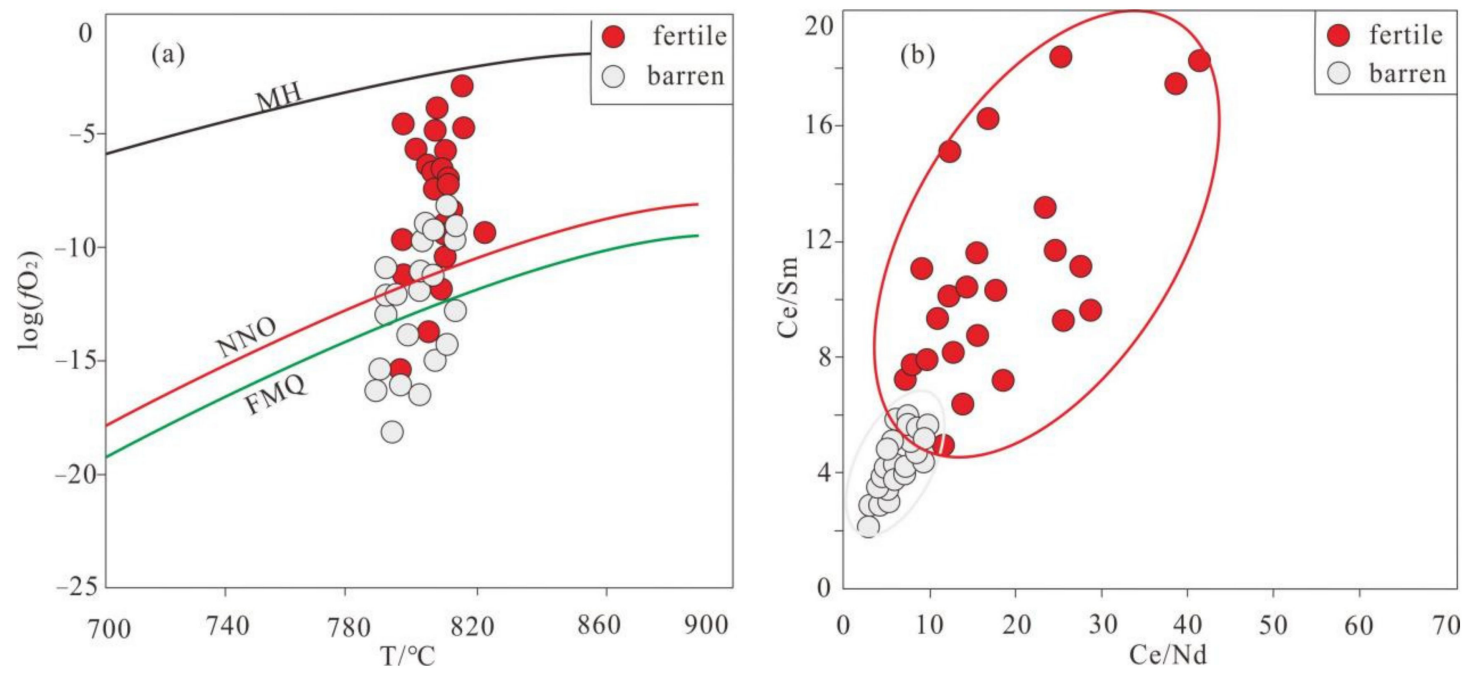

Figure 11. (a) Plots of $\mathrm{T}\left({ }^{\circ} \mathrm{C}\right)$ vs. $\log \left(f \mathrm{O}_{2}\right)$ in zircon. magnetite-hematite $(\mathrm{MH})$ buffer line is from [102]; nickle-nickle oxide (NNO) buffer curve is from [103]; fayalite-magnetite-quartz (FMQ) buffer curve is from [104]. (b) Plots of Ce/Nd vs. Ce/Sm in zircon.
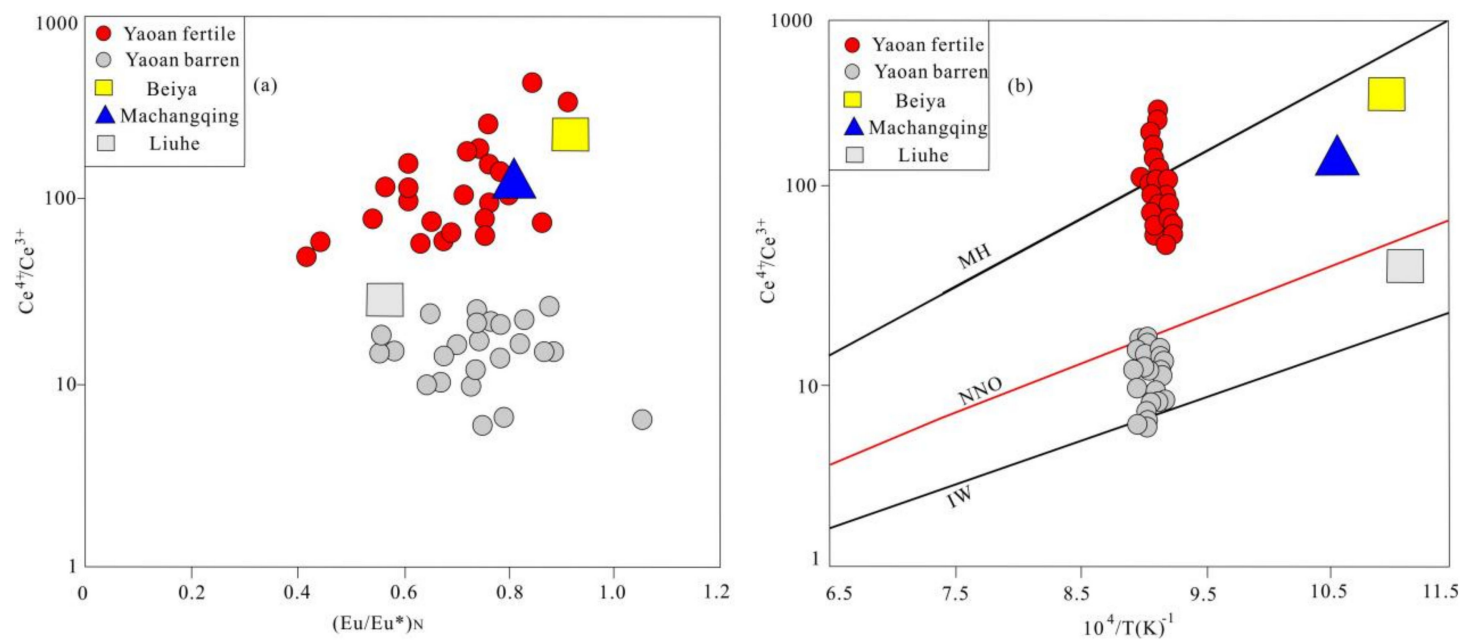

Figure 12. (a) Plots of $\delta$ Eu vs. $\mathrm{Ce}^{4+} / \mathrm{Ce}^{3+}$ in zircon. (b) Plots of $\mathrm{Ce}^{4+} / \mathrm{Ce}^{3+}$ vs. $10^{4} / \mathrm{T}$ in zircon. $\mathrm{High} \mathrm{Ce}^{4+} / \mathrm{Ce}^{3+}$ ratio signifies high oxygen fugacity. The Yao'an data are compared with those from the Beiya porphyry [6], Machangjing porphyry [32], and Liuhe porphyry [39], using the equation of [105].

Silicate melts with high oxygen fugacity can suppress sulfide saturation and therefore depletion of chalcophile elements (e.g., $\mathrm{Cu}$ ) that are in forms of sulfide, which allows gathering of $\mathrm{Cu}$ in the $\mathrm{Cl}-\mathrm{S}$ bearing fluid phase [106-111]. Therefore, a high oxygen fugacity is more likely to lead to the development of porphyry deposits.

\subsection{Implications for the Magmatic Source}

Previous studies have shown that Hf isotopic compositions of the chondrites and depleted mantle are different from those of the enriched lithospheric mantle and crust. Generally, ${ }^{176} \mathrm{Hf} /{ }^{177} \mathrm{Hf}$ ratios of chondrites and depleted mantle $\left({ }^{176} \mathrm{Hf} /{ }^{177} \mathrm{Hf}>0.283335\right.$, $\varepsilon H f>0)$ show a more radiogenic character than that of enriched lithospheric mantle and crustal components $(\varepsilon \mathrm{Hf}<0)[64,112,113]$.

The Beiya and Machangqing alkali-rich porphyries, which are located near the Jinshajiang-Ailaoshan suture at the edge of the Yangtze plate, have high zircon $\varepsilon H f$ (Beiya: -4 to 4; Machangqing: 0.3 to 4.7 ) value and young two-stage Hf depleted mantle-model ages (Beiya: 0.85 to $1.37 \mathrm{Ga}$; Machangqing: 1.1 to $0.8 \mathrm{Ga}$ ) are considered to be derived from thickened juvenile lower crust mixed with lithospheric mantle [31,47]. In this paper, strong 
negative zircon $\varepsilon$ Hf values (-15.24 to -7.75$)$ and adakite-like rocks of the Yao'an fertile and barren porphyry, as well as the high $f \mathrm{O}_{2}$ and apatite $\mathrm{S}-\mathrm{Cl}$ contents, may indicate that the Yao'an intrusions are all derived from partial melting of the thickened lower crustal materials that have been modified by slab-derived fluids. Ancient two-stage Hf model ages $(2.04$ to $1.57 \mathrm{Ga}$ ) indicate that the crustal components maybe the PaleoproterozoicMesoproterozoic metamorphic basement.

\section{Conclusions}

According to the analysis of apatite and zircon from barren and fertile porphyry, the following conclusions can be drawn.

(1) REE contents in apatite and zircon can be used to reveal the crystallization sequence of minerals and are good indicators of adakitic rock.

(2) $\mathrm{Y} / \mathrm{Ho}$ and $\mathrm{Zr} / \mathrm{Hf}$ ratios in zircon and $\mathrm{Cl}$ contents variation in apatite from fertile porphyry indicate fertile porphyry has stronger fluid activity and experienced exsolution of Cl-bearing hydrothermal.

(3) The high S, V, As contents, $\delta \mathrm{Eu}$, low $\delta \mathrm{Ce}$ in apatite, as well as high $\mathrm{Ce}^{4+} / \mathrm{Ce}^{3+}$ and $\log \left(f \mathrm{O}_{2}\right)$ estimated from zircon geochemistry from fertile porphyry, indicate high oxidation state of fertile porphyry, similar to other fertile porphyries in this metallogenic belt.

(4) In situ zircon Hf isotopic data show that Yao'an intrusions were derived from partial melting of the thickened lower crust that have been modified by slab-derived fluids.

Supplementary Materials: The following are available online at https://www.mdpi.com/article/10 $.3390 / \min 11111293 / \mathrm{s} 1$, Table S1: Apatite major-trace elements compositions, Table S2: Zircon trace elements and isotopic compositions.

Author Contributions: Formal analysis, F.J.; funding acquisition, C.Z.; investigation, F.J. and Q.Y.; software, H.L.; writing—original draft, Y.Z.; writing—review \& editing, Y.Z. and C.Z. All authors have read and agreed to the published version of the manuscript.

Funding: This research was funded by the National Key Research and Development Program of China (2016YFC0600305) and the Program of the China Geological Survey (41602103).

Informed Consent Statement: Informed consent was obtained from all subjects involved in this study.

Acknowledgments: We appreciate Jinmeng Hu, Xiaochuan Du and Qingyao Lan for their help in fieldwork.

Conflicts of Interest: The authors declare no conflict of interest.

\section{References}

1. Henerson, P. Rare earth element partition between sphene, apatite and other coexisting minerals at the Kangerdlugssuag Intrusion, East Greenland. Contrib. Mineral. Petrol. 1980, 72, 81-85. [CrossRef]

2. Belousova, E.A.; Walters, S.; Griffin, W.L.; O'Reilly, S.Y. Trace-element signatures of apatites in granitoids from the Mt Isa Inlier, northwestern Queensland. Aust. J. Earth Sci. 2001, 48, 603-619. [CrossRef]

3. Piccoli, P.M.; Candela, P.A. Apatite in igneous systems. Rev. Miner. Geochem. 2002, 48, 255-292. [CrossRef]

4. Webster, J.D.; Piccoli, P.M. Magmatic apatite: A powerful yet deceptive. Miner. Elem. 2015, 11, 177-182. [CrossRef]

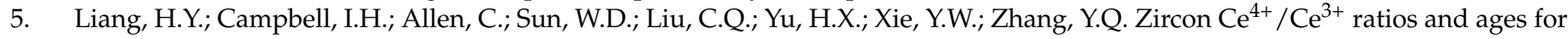
Yulong metallogenetic porphyry in eastern Tibet. Miner. Depos. 2006, 41, 152-159. [CrossRef]

6. Jiang, C.Z.; Wang, Q.F.; Li, G.J.; Ma, N.; Hu, Z.C. Relative oxidation states of intrusions in Beiya gold-polymetallic deposit in Sanjiang area, Yunnan, SW China. Acta Petrol. Sin. 2013, 29, 3925-3936.

7. Pan, L.C.; Hu, R.Z.; Wang, X.S.; Bi, X.W.; Zhu, J.J.; Li, C. Apatite trace element and halogen compositions as petrogeneticmetallogenic indicators: Examples from four granite plutons in the Sanjiang region, SW China. Lithos 2016, 254, 118-130. [CrossRef]

8. Lu, Y.J.; Loucks, R.R.; Fiorentini, M.L.; McCuaig, T.C.; Evans, N.J.; Yang, Z.M.; Hou, Z.Q.; Kirkland, C.L.; Parra-Avila, L.A.; Kobussen, A. Zircon compositions as a pathfinder for porphyry $\mathrm{Cu} \pm \mathrm{Mo} \pm \mathrm{Au}$ deposits. Soc. Econ. Geol. Spec. Pub. 2016, 19, 329-347.

9. Yang, L.Q.; Deng, J.; Gao, X.; He, W.Y.; Meng, J.Y.; Santosh, M.; Yu, H.J.; Yang, Z.; Wang, D. Timing of formation and origin of the Tongchanggou porphyry-skarn deposit: Implications for Late Cretaceous Mo-Cu metallogenesis in the southern Yidun Terrane, SE Tibetan Plateau. Ore Geol. Rev. 2017, 81, 1015-1032. [CrossRef] 
10. Meng, X.Y.; Mao, J.W.; Zhang, C.Q.; Zhang, D.Y.; Liu, H. Melt recharge, fO2 -T conditions, and metal fertility of felsic magmas: Zircon trace element chemistry of $\mathrm{Cu}-\mathrm{Au}$ porphyries in the Sanjiang orogenic belt, southwest China. Miner. Depos. 2018, 53, 649-663. [CrossRef]

11. Jia, F.D.; Zhang, C.Q.; Liu, H.; Meng, X.Y.; Kong, Z.G. In situ major and trace element compositions of apatite from the Yangla skarn Cu deposit, southwest China: Implications for petrogenesis and mineralization. Ore Geol. Rev. 2020, 127, 103360. [CrossRef]

12. Sha, L.K.; Chappell, B.W. Apatite chemical composition by electron microprobe and laser-ablation inductively coupled plasma spectrometry, as a probe into granite petrogenesis. Geochim. Cosmochim. Acta 1999, 63, 3861-3881. [CrossRef]

13. Miles, A.J.; Graham, C.M.; Hawkesworth, C.J.; Gillespie, M.R.; Hinton, R.W.; Bromiley, G.D. Apatite: A new redox proxy for silicic magmas. Geochim. Cosmochim. Acta 2014, 132, 101-119. [CrossRef]

14. Boudreau, A.E.; Kruger, F.J. Variation in the composition of apatite through the Merensky cyclic unit in the western Bushveld Complex. Econ. Geol. 1990, 85, 737-745. [CrossRef]

15. Boyce, J.W.; Liu, Y.; Rossman, G.R.; Guan, Y.B.; Eiler, J.M.; Stolper, E.M.; Taylor, L.A. Lunar apatite with terrestrial volatile abundances. Nature 2010, 466, 462-466. [CrossRef] [PubMed]

16. Schisa, P.; Boudreau, A.; Djon, L.; Tchalikian, A.; Corkery, J. The Lac des Iles Palladium Deposit, Ontario, Canada. Part II. Halogen Variations in Apatite. Miner. Depos. 2015, 50, 339-355. [CrossRef]

17. Ballard, J.R.; Palin, M.J.; Campbell, I.H. Relative oxidation states of magmas inferred from Ce(IV)/Ce(III) in zircon: Application to porphyry copper deposits of northern Chile. Contrib. Mineral. Petrol. 2002, 144, 347-364. [CrossRef]

18. Xin, H.B.; Qu, X.M. Relative oxidation states of metallogenetic porphyries inferred from Ce(IV)/Ce(III) ratio in zircon: Application to the porphyry copper belt at Gangdese, Tibet. Acta Mineral. Sin. 2008, 28, 151-160.

19. Trail, D.; Watson, E.B.; Tailby, N.D. The oxidation state of Hadean magmas and implications for early Earth's atmosphere. Nature 2011, 480, 79-82. [CrossRef]

20. Liang, H.Y.; Mo, J.H.; Sun, W.D.; Yu, H.X.; Zhang, Y.Q.; Allen, C.M. Study on the duration of the ore-forming system of the Yulong giant porphyry copper deposit in eastern Tibet, China. Acta Petrol. Sin. 2008, 24, 2352-2358.

21. Xu, L.L.; Bi, X.W.; Hu, R.Z.; Zhang, X.C.; Su, W.C.; Qu, W.J.; Hu, Z.C.; Tang, Y.Y. Relationships between porphyry Cu-Mo mineralization in the Jinshajiang-Red River metallogenic belt and tectonic activity: Constraints from zircon U-Pb and molybdenite Re-Os geochronology. Ore Geol. Rev. 2012, 48, 460-473. [CrossRef]

22. He, W.Y.; Mo, X.X.; He, Z.H.; White, N.C.; Chen, J.B.; Yang, K.H.; Wang, R.; Yu, X.H.; Dong, G.C.; Huang, X.F. The geology and mineralogy of the beiya skarn gold deposit in Yunnan, southwest China. Econ. Geol. 2015, 110, 1625-1641. [CrossRef]

23. Liu, M.; Song, S.W.; Cui, Y.R.; Chen, G.H.; Rao, J.F.; Ouyang, Y.P. In-situ U-Pb geochronology and trace element analysis for the scheelite and apatite from the deep seated stratiform-like $\mathrm{W}(\mathrm{Cu})$ ore of the Zhuxi tungsten deposit, northeastern Jiangxi Province. Acta Petrol. Sin. 2021, 37, 717-732.

24. Hou, Z.Q.; Ma, H.W.; Zaw, K.; Zhang, Y.Q.; Wang, M.J.; Wang, Z.; Pan, G.T.; Tang, R.L. The Himalayan Yulong porphyry copper belt: Product of large-scale strike-slip faulting in eastern Tibet. Econ. Geol. 2003, 98, 125-145.

25. Li, J.X.; Qin, K.Z.; Li, G.L.; Cao, M.J.; Chen, L. Petrogenesis and thermal history of the Yulong porphyry copper deposit, Eastern Tibet: Insights from $\mathrm{U}-\mathrm{Pb}$ and $\mathrm{U}-\mathrm{Th} / \mathrm{He}$ dating, and zircon $\mathrm{Hf}$ isotope and trace element analysis. Mineral. Petrol. 2012, 105, 201-221. [CrossRef]

26. Yang, Z.M.; Hou, Z.Q.; Zhou, L.M.; Zhou, Z.H. Critical elements in porphyry copper deposits of China. Chin. Sci. Bull. 2020, 65, 3653-3664. [CrossRef]

27. He, W.Y.; Mo, X.X.; Yu, X.H.; He, Z.H.; Dong, G.C.; Liu, X.B.; Su, G.S.; Huang, X.F. Zircon U-Pb and molybdenite Re-Os dating for the Beiya gold-polymetallic deposit in the western Yunnan Province and its geological significance. Acta Petrol. Sin. 2013, 29, 1301-1310.

28. Bao, X.S.; Yang, L.Q.; He, W.Y. Importance of magmatic water content and oxidation state for porphyry-style Au minerazation: An example from the Giant Beiya Au deposit, SW China. Minerals 2018, 8, 441. [CrossRef]

29. Liu, S.Q.; Zheng, Y.C.; Shen, Y.; Hou, Z.Q.; Wang, L.; Wang, Z.X. Source of the ore-forming Adakitic porphyry at the Beiya super-large Au deposit, Western Yangtze Craton: New evidence from Zircon U-Pb ages of the amphibolite xenoliths. Acta Geol. Sin. 2020, 94, 208-209. [CrossRef]

30. Hu, R.; Burnard, P.G.; Turner, G. Helium and Argon isotope systematics in fluid inclusions of Machangqing copper deposit in west Yunnan province, China. Chem. Geol. 1998, 146, 55-63. [CrossRef]

31. Lu, Y.J.; Kerrich, R.; Mccuaig, T.C.; Li, Z.X.; Hart, C.J.; Cawood, P.A.; Hou, Z.Q.; Bagas, L.; Cliff, J.; Belousova, E.A.; et al Geochemical, $\mathrm{Sr}-\mathrm{Nd}-\mathrm{Pb}$, and Zircon Hf-O isotopic compositions of Eocene-Oligocene shoshonitic and potassic adakite-like felsic intrusions in Western Yunnan, SW China: Petrogenesis and tectonic implications. J. Petrol. 2013, 54, 1309-1348. [CrossRef]

32. Liang, H.Y.; Xie, Y.W.; Zhang, Y.Q.; Campbell, I.H. Constraints to the mineralization of the copper deposits from forming and evolution of potassium-rich alkali rock at Machangqing copper deposits. Prog. Nat. Sci. 2004, 14, 116-119.

33. Shen, Y.; Zheng, Y.C.; Ma, R.; Zhang, A.P.; Xu, P.Y.; Wu, C.D.; Wang, Z.X. Mineralogical characteristics of hornblendes and biotites in ore-forming porphyry from Machangqing Cu-Mo deposit in Yunnan Province and their significance. Miner. Depos. 2018, 37, 797-815.

34. Bi, X.W.; Cornell, D.H.; Hu, R.Z. REE composition of primary and altered feldspar from the mineralized alteration zone of alkaline intrusive rocks, western Yunnan Province, China. Ore Geol. Rev. 2002, 19, 69-78. [CrossRef] 
35. Bi, X.; Hu, R.; Cornell, D.H. The alkaline porphyry associated Yao'an gold deposit, Yunnan, China: Rare earth element and stable isotope evidence for magmatic-hydrothermal ore formation. Miner. Depos. 2004, 39, 21-30. [CrossRef]

36. Bi, X.W.; Hu, R.Z.; Peng, J.T.; Wu, K.X.; Su, W.C.; Zhang, X.Z. Geochemical characteristic of the Yao'an and Machangqing alkaline-rich instrusions. Acta Petrol. Sin. 2005, 21, 113-124.

37. Bi, X.W.; Hu, R.Z.; Hanley, J.J.; Mungall, J.E.; Peng, J.T.; Shang, L.B.; Wu, K.X.; Suang, Y.; Li, H.L.; Hu, X.Y. Crystallisation conditions $\left(\mathrm{T}, \mathrm{P}, \mathrm{fO}_{2}\right)$ from mineral chemistry of $\mathrm{Cu}$-and $\mathrm{Au}$-mineralised alkaline intrusions in the Red River-Jinshajiang alkaline igneous belt, western Yunnan Province, China. Mineral. Petrol. 2009, 96, 43-58.

38. Yan, Q.G.; Jiang, X.J.; Li, C.; Zhou, L.M.; Wang, Z.Q.; Baig, S.; Qu, W.J.; Du, A.D. Geodynamic background of intracontinental cenozoic alkaline volcanic rocks in Laojiezi, Western Yangtze Craton: Constraints from Sr-Nd-Hf-O Isotopes. Acta Geol. Sin. 2018, 92, 2098-2119.

39. Zhou, Y.; Shen, Y.; Hou, Z.Q.; Xie, X.; Luo, C. Amphibole, biotite and zircon charactedstics of Liuhe orthophyre in western Yunnan and their implications. Acta Petrol. Miner. 2018, 37, 29-43.

40. Luo, C.H.; Zhou, Y.; Shen, Y. The geochemical characteristics and petrogenesis of the mineralized Alkali-rich magmatic rock in Yao'an Au-Pb-Ag deposit, Yunnan Province. Earth Sci. 2019, 44, 2063-2083.

41. Zhu, X.P.; Mo, X.X.; White, N.C.; Sun, M.X.; Zhao, S.L. Fluid inclusions of Habo porphyry Cu-(Mo-Au) deposit, Yunnan Provinc. Miner. Depos. 2012, 31, 839-849.

42. Zhu, X.P.; Mo, X.X.; White, N.C.; Zhang, B.; Sun, M.X.; Wang, S.X.; Zhao, S.L.; Yang, Y. Petrogenesis and metallogenic setting of the Habo porphyry Cu-(Mo-Au) deposit, Yunnan, China. J. Asian Earth Sci. 2013, 66, 188-203. [CrossRef]

43. Meng, Z.N.; Zhang, Q.; Ye, L.; Liu, Y.P.; Lan, J.B. The genetic relationship between Habo alkaline intrusion and its surrounding deposits, Yunnan Province, China: Geological and S-Pb isotopic evidences. Acta Geochim. 2016, 35, 391-407. [CrossRef]

44. Zhang, Y.Q.; Xie, Y.W.; Tu, G.Z. Preliminary studies of the alkali-rich intrusive rocks in the Ailaoshan-Jinshajiang belt and their bearing on rift tectonics. Acta Petrol. Sin. 1987, 1, 17-26.

45. Metcalfe, I. Gondwana dispersion and Asian accretion: Tectonic and palaeogeographic evolution of eastern Tethys. J. Asian Earth Sci. 2013, 66, 1-33. [CrossRef]

46. Hou, Z.Q.; Zhao, Z.D.; Gao, Y.F.; Yang, Z.M.; Jiang, W. Tearing and dischronal subduction of the Indian continental slab: Evidence from Cenozoic Gangdese volcano-magmatic rock in south Tibet. Acta Petrol. Sin. 2006, 22, 761-774.

47. Deng, J.; Wang, Q.F.; Li, G.J.; Li, C.S.; Wang, C.M. Tethys tectonic evolution and its bearing on the distribution of important mineral deposits in the Sanjiang region, SW China. Gondwana Res. 2014, 26, 419-437. [CrossRef]

48. Tapponnier, P.; Lacassin, R.; Leloup, P.H.; Schärer, U.; Zhong, D.L.; Wu, H.W.; Liu, X.H.; Ji, S.C.; Zhang, L.S.; Zhong, J.Y. The Ailao Shan/Red River metamorphic belt: Tertiary left-lateral shear between Indochina and South China. Nature 1990, 343, $431-437$. [CrossRef]

49. Yin, A.; Harrison, T.M. Geologic evolution of the Himalayan-Tibetan orogen. Annu. Rev. Earth Planet. Sci. 2000, 28, 211-280. [CrossRef]

50. Zi, J.W.; Cawood, P.A.; Fan, W.M.; Tohver, E.; Wang, Y.J.; Mccuaig, T.C.; Peng, T.P. Late Permian-Triassic magmatic evolution in the Jinshajiang orogenic belt, SW China and implications for orogenic processes following closure of the Paleo-Tethys. Am. J. Sci. 2013, 313, 81-112. [CrossRef]

51. Hou, Z.Q.; Zaw, K.; Pan, G.T.; Mo, X.X.; Xu, Q.; Hu, Y.Z.; Li, X.Z. Sanjiang Tethyan metallogenesis in SW China: Tectonic setting, metallogenic epochs and deposit types. Ore Geol. Rev. 2007, 31, 48-87. [CrossRef]

52. Hou, Z.Q.; Zheng, Y.C.; Yang, Z.M.; Yang, Z.S. Metallogenesis of continental collision setting: Part I. Gangdese Cenozoic porphyry Cu-Mo systems in Tibet. Miner. Depos. 2012, 31, 647-670.

53. Lu, Y.J.; Kerrich, R.; Cawood, P.A.; McCuaig, T.C. Zircon SHRIMP U-Pb geochronology of potassic felsic intrusions in western Yunnan, SW China: Constraints on the relationship of magmatism to the Jinsha suture. Gondwana Res. 2012, 22, 737-747. [CrossRef]

54. Sun, W.H.; Zhou, M.F.; Gao, J.F.; Yang, Y.H.; Zhao, X.F.; Zhao, J.H. Detrital zircon U-Pb geochronological and Lu-Hf isotopic constraints on the Precambrian magmatic and crustal evolution of the western Yangtze Block, SW China. Pricamb. Res. 2009, 172, 99-126. [CrossRef]

55. Pan, G.T.; Chen, Z.L.; Li, X.Z. Tectonic Evolution of the East Tethys Geology; Geological Publishing House: Beijing, China, $1997 ;$ p. 257.

56. Chung, S.L.; Lo, C.H.; Lee, T.Y.; Zhang, Y.Q.; Xie, Y.W.; Li, X.H.; Wang, K.L.; Wang, P.L. Diachronous uplift of the Tibetan plateau starting 40 Myr ago. Nature 1998, 394, 769-773. [CrossRef]

57. Wang, J.H.; Yin, A.; Harrison, T.M.; Grove, M.; Zhang, Y.Q.; Xie, G.H. A tectonic model for Cenozoic igneous activities in the eastern Indo-Asian collision zone. Earth Planet. Sci. Lett. 2001, 188, 123-133. [CrossRef]

58. Ge, L.S.; Guo, X.D.; Zhou, Y.L.; Yang, J.H.; Li, Y.J. Geology and genesis of the Yao'an gold deposit related to alkali-rich magmatic rock in Yunnan province. Geol. Res. 2002, 1, 29-37.

59. Qian, X.G.; Li, Z.W. Geological and geochemical characteristics of the Yao'an gold ore deposit in central Yunnan. Geotect. Metal. 2000, 24, 31-36.

60. Cheng, J.; Xia, B.; Zhang, Y.Q. Petrological and geochemical characteristics of Yao'an alkaline complex in Yunnan province. Geotect. Metal. 2007, 31, 118-125.

61. Hou, K.J.; Li, Y.H.; Zou, T.R.; Qu, X.M.; Shi, Y.R.; Xie, G.Q. Laser ablation-MC-ICP-MS technique for Hf isotope microanalysis of zircon and its geological applications. Acta Petrol. Sin. 2007, 23, 2595-2604. 
62. Elhlou, S.; Belousova, E.; Griffin, W.L.; Pearson, N.J.; O’Reilly, S.Y. Trace element and isotopic composition of GJ-red zircon standard by laser ablation. Geochim. Cosmochim. Acta 2006, 70, A158. [CrossRef]

63. Blichert-Toft, J.; Chauvel, C.; Albarede, F. Separation of Hf and Lu for high-precision isotope analysis of rock samples by magnetic sector-multiple collector ICP-MS. Contrib. Mineral. Petrol. 1997, 127, 248-260. [CrossRef]

64. Griffin, W.L.; Pearson, N.J.; Belousova, E.; Jackson, S.E.; Achterbergh, E.V.; O'Reilly, S.Y.; Shee, S.R. The Hf isotope composition of cratonic mantle: LAM-MC-ICPMS analysis of zircon megacrysts in kimberlites. Geochim. Cosmochim. Acta 2000, 64, $133-147$. [CrossRef]

65. Griffin, W.J.; Wang, X.; Jackson, S.E.; Pearson, N.J.; O’Reilly, S.Y.; Xu, X.S.; Zhou, X.M. Zircon chemistry and magma mixing, SE China: In-situ analysis of Hf isotopes, Tonglu and Pingtan igneous complexes. Lithos 2002, 61, 237-269. [CrossRef]

66. Yao, C.L.; Lu, J.J.; Guo, W.M. Compositional difference between three generations of apatite from Tongchang porphyry copper deposit, Jiangxi Privince, Southeast China. Acta Mineral. Sin. 2007, 27, 31-40.

67. Sun, S.S.; McDonough, W.S. Chemical and isotopic systematics of oceanic basalts: Implications for mantle composition and processes. Geol. Soc. Lond. Spec. Pub. 1989, 42, 313-345. [CrossRef]

68. Belousova, E.A.; Griffin, W.L.; O’Reilly, S.Y.; Fisher, N.I. Apatite as an indicator mineral for mineral exploration: Trace-element compositions and their relationship to host rock type. J. Geochem. Explor. 2002, 76, 45-69. [CrossRef]

69. Miller, C.F.; McDowell, S.M.; Mapes, R.W. Hot and cold granites implications of zircon saturation temperatures and preservation of inheritance. Geology 2003, 31, 529-532. [CrossRef]

70. Miller, J.S.; Wooden, J.L. Residence, resorption and recycling of zircons in Devils Kitchen Rhyolite, Coso volcanic feld, California. J. Petrol. 2004, 45, 2155-2170. [CrossRef]

71. Grimes, C.B.; Wooden, J.L.; Cheadle, M.J.; John, B.E. “Fingerprinting” tectono-magmatic provenance using trace elements in igneous zircon. Contrib. Mineral. Petrol. 2015, 170, 46. [CrossRef]

72. Lee, R.G.; Dilles, J.H.; Tosdal, R.M.; Wooden, J.L.; Mazdab, F.K. Magmatic evolution of granodiorite intrusions at the El Salvador porphyry copper deposit, Chile, based on trace element composition and U/Pb age of zircons. Econ. Geol. 2017, 112, 245-273. [CrossRef]

73. Xie, F.W.; Tang, J.X.; Chen, Y.C.; Lang, X.H. Apatite and zircon geochemistry of Jurassic porphyries in the Xiongcun district, southern Gangdese porphyry copper belt: Implications for petrogenesis and mineralization. Ore Geol. Rev. 2018, 96, 98-114. [CrossRef]

74. Hoskin, P.W.O.; Kinny, P.D.; Wyborn, D.; Chappell, B.W. Identifying accessory mineral saturation during differentiation in granitoid magmas: An integrated approach. J. Petrol. 2000, 41, 1365-1396. [CrossRef]

75. Miles, A.J.; Graham, C.M.; Hawkesworth, C.J.; Gillespie, M.R.; Hinton, R.W. Evidence for distinct stages of magma history recorded by the compositions of accessory apatite and zircon. Contrib. Mineral. Petrol. 2013, 166, 1-19. [CrossRef]

76. Barth, S.; Oberli, F.; Meier, M. Th-Pb versus U-Pb isotope systematics in allanite from cogenetic rhyolite and granodiorite: Implications for geochronology. Earth Planet. Sci. Lett. 1990, 124, 149-159. [CrossRef]

77. Ferry, J.M.; Watson, E.B. New thermodynamic models and revised calibrations for the Ti-in-zircon and Zr-in-rutile thermometers. Contrib. Mineral. Petrol. 2007, 154, 429-437. [CrossRef]

78. Jochum, K.P.; Mcdonough, W.F.; Palme, H.; Spettel, B. Compositional constraints on the continental lithospheric mantle from trace elements in spinel peridotite xenoliths. Nature 1989, 340, 548-550. [CrossRef]

79. Candela, P.A.; Holland, H.D. A mass transfer model for copper and molybdenum in magmatic hydrothermal systems: The origin of porphyry-type ore deposits. Econ. Geol. 1986, 81, 1-19. [CrossRef]

80. Flynn, R.T.; Burnham, C.W. An experiment determination of rare earth partition coefficients between chlorine containing vapor and silicate melts. Geochim. Cosmochim. Acta 1978, 42, 685-701. [CrossRef]

81. Keppler, H.; Wyllie, P.J. Partitioning of $\mathrm{Cu}, \mathrm{Sn}, \mathrm{Mo}, \mathrm{W}, \mathrm{U}$, and Th between melt and aqueous fluid in the systems haplogranite$\mathrm{H}_{2} \mathrm{O}-\mathrm{HCl}$ and haplogranite- $\mathrm{H}_{2} \mathrm{O}-\mathrm{HF}$. Contrib. Mineral. Petrol. 1991, 109, 139-150. [CrossRef]

82. Webster, J.D.; Tappen, C.M.; Mandeville, C.W. Partitioning behavior of chlorine and fluorine in the system apatite-melt-fluid. II: Felsic silicate systems at 200MPa. Geochim. Cosmochim. Acta 2009, 73, 559-581. [CrossRef]

83. John, T.; Scambelluri, M.; Frische, M.; Barnes, J.D.; Bach, W. Dehydration of subducting serpentinite: Implications for halogen mobility in subduction zones and the deep halogen cycle. Earth Planet. Sci. Lett. 2011, 308, 65-76. [CrossRef]

84. Williams-Jones, A.E.; Migdisov, A.A.; Samson, I.M. Hydrothermal mobilisation of the Rare Earth Elements-A Tale of "Ceria" and "Yttria". Elements 2012, 8, 355-360. [CrossRef]

85. Wang, R.; Richards, J.P.; Hou, Z.Q.; Yang, Z.M.; DuFrane, S.A. Increased magmatic water content: The key to Oligo-Miocene porphyry Cu-Mo \pm Au formation in the eastern Gangdese belt, Tibet. Econ. Geol. 2014, 109, 1315-1339. [CrossRef]

86. Kusebauch, C.; John, T.; Whitehouse, M.J.; Klemme, S.; Putnis, A. Distribution of halogens between fluid and apatite during fluid-mediated replacement processes. Geochim. Cosmochim. Acta 2015, 170, 225-246. [CrossRef]

87. Burnham, C.W. Magmas and hydrothermal fluids. Geoch. Hydroth. Ore Depos. 1979, 2, 71-136.

88. Simon, A.C.; Pettke, T.; Candela, P.A.; Piccoli, P.M.; Heinrich, C.A. Experimental determination of Au solubility in rhyolitemelt and magnetite: Constraints on magmatic Au budgets. Am. Mineral. 2003, 88, 1644-1651. [CrossRef]

89. Robb, L. Introduction to Ore-Forming Processes; Blackwell Publishing: Hoboken, NJ, USA, 2005; pp. 1-386.

90. Watson, E.B.; Green, T.H. Apatite/liquid partition coefficients for the rare earth elementsand strontium. Earth Planet. Sci. Lett. 1981, 56, 405-421. [CrossRef] 
91. Pan, Y.; Fleet, M.E. Compositions of the Apatite-group minerals: Substitution mechanisms and controlling factors. Rev. Miner. Geoch. 2002, 48, 13-49. [CrossRef]

92. Imai, A. Metallogenesis of porphyry $\mathrm{Cu}$ deposits of the Western Luzon Arc, Philippines: $\mathrm{K}-\mathrm{Ar}$ ages, $\mathrm{SO}_{3}$ contents of microphenocrystic apatite and significance of intrusive rocks. Res. Geol. 2002, 52, 147-161. [CrossRef]

93. Imai, A. Variation of $\mathrm{Cl}$ and $\mathrm{SO}_{3}$ contents of microphenocrystic apatite in intermediate to silicic igneous rocks of cenozoic Japanese Island Arcs: Implications for porphyry Cu metallogenesis in the Western Pacific Island Arcs. Resour. Geol. 2004, 54, 357-372. [CrossRef]

94. Parat, F.; Holtz, F. Sulfur partition coefficient between apatite and rhyolite: The role of bulk S content. Contrib. Mineral. Petrol. 2005, 150, 643-651. [CrossRef]

95. Chu, M.F.; Wang, K.L.; Griffin, W.L.; Chung, S.L.; O’Reilly, S.Y.; Pearson, N.J.; Iizuka, Y. Apatite composition: Tracing petrogenetic processes in transhimalayan granitoids. J. Petrol. 2009, 50, 1829-1855. [CrossRef]

96. Cao, M.J.; Li, G.M.; Qin, K.Z.; Seitmuratova, E.Y.; Liu, Y. Major and trace element characteristics of apatites in granitoids from central Kazakhstan: Implications for petrogenesis and mineralization. Res. Geol. 2012, 62, 63-83. [CrossRef]

97. Mao, M.; Rukhlov, A.S.; Rowins, S.M.; Spence, J.; Coogan, L.A. Apatite trace element compositions: A robust new tool for mineral exploration. Econ. Geol. 2016, 111, 1187-1222. [CrossRef]

98. Konecke, B.A.; Fiege, A.; Simon, A.C.; Parat, F.; Stechern, A. Co-variability of $\mathrm{S}^{6+}, \mathrm{S}^{4+}$, and $\mathrm{S}^{2-}$ in apatite as a function of oxidation state: Implications for a new oxybarometer. Am. Mineral. 2017, 102, 548-557. [CrossRef]

99. Shen, P.; Hattori, K.; Pan, H.; Jackson, S.; Seitmuratova, E. Oxidation condition and metal fertility of granitic magmas: Zircon trace-element data from porphyry $\mathrm{Cu}$ deposits in the central Asian orogenic belt. Econ. Geol. 2015, 110, 1861-1878. [CrossRef]

100. Trail, D.; Watson, E.B.; Tailby, N.D. Ce and Eu anomalies in zircon as proxies for the oxidation state of magmas. Geochim. Cosmochim. Acta 2012, 97, 70-87. [CrossRef]

101. Watson, E.B.; Harrison, T.M. Response to comments on "Zircon thermometer reveals minimum melting conditions on earliest Earth". Science 2006, 311, 779. [CrossRef]

102. Chou, I.M. Calibration of oxygen buffers at elevated P and T using the hydrogen fugacity sensor. Am. Mineral. 1978, 63, 690-703.

103. Huebner, J.S.; Sato, M. The oxygen fugacity-temperature relationships of manganese oxide and nickel oxide buffers. Am. Mineral. 1970, 55, 934-952.

104. Huebner, J.S. Buffering Techniques for Hydrostatic Systems at Elevated Pressure; Springer: Berlin/Heidelberg, Germany, 1971; pp. 123-177.

105. Ridolfi, F.; Renzulli, A.; Puerini, M. Stability and chemical equilibrium of amphibole in calc-alkaline magmas: An overview, new thermo barometric formulations and application to subduction-related volcanoes. Contrib. Mineral. Petrol. 2010, 160, 45-66. [CrossRef]

106. Candela, P.A. Controls on ore metal ratios in granite-related ore systems: An experimental and computational approach. Transactions. Royal Society. Edinb. Earth Sci. 1992, 83, 317-326.

107. Oyarzun, R.; Márquez, A.; Lillo, J.; López, I.; Rivera, S. Giant versus small porphyry copper deposits of Cenozoic age in northern Chile: Adakitic versus normal calc-alkaline magmatism. Miner. Depos. 2001, 36, 794-798. [CrossRef]

108. Cline, J. Genesis of porphyry copper deposits: The behavior of water, chloride, and copper in crystallizing melts. Arizona Geol. Soc. Digest. 1995, 20, 69-82.

109. Richards, J. Postsubduction porphyry $\mathrm{Cu}-\mathrm{Au}$ and epithermal Au deposits: Products of remelting of subduction-modified lithosphere. Geology 2009, 37, 247-250. [CrossRef]

110. Botcharnikov, R.E.; Linnen, R.L.; Wilke, M.; Holtz, F.; Jugo, P.J.; Berndt, J. High gold concentrations in sulphide-bearing magma under oxidizing conditions. Nat. Geol. 2010, 4, 112. [CrossRef]

111. Sun, W.D.; Huang, R.F.; Li, H.; Hu, Y.B.; Zhang, C.C.; Sun, S.J.; Zhang, L.P.; Ding, X.; Li, C.Y.; Zartman, R.E.; et al. Porphyry deposits and oxidized magmas. Ore Geol. Rev. 2015, 65, 97-131. [CrossRef]

112. Peter, D.K.; Roland, M. Lu-Hf and Sm-Nd isotope system in zircon. Rev. Miner. Geochem. 2003, 53, 327-341.

113. Wu, F.Y.; Li, X.H.; Zheng, Y.F.; Gao, S. Lu-Hf isotopic systematics and their applications in petrology. Acta Petrol. Sin. 2007, 23, 185-220. 